Anais da Academia Brasileira de Ciências (2004) 76(4): 663-698

(Annals of the Brazilian Academy of Sciences)

ISSN 0001-3765

www.scielo.br/aabc

\title{
On the geographical differentiation of Gymnodactylus geckoides Spix, 1825 (Sauria, Gekkonidae): speciation in the Brasilian caatingas
}

\author{
PAULO EMILIO VANZOLINI*
}

\author{
Museu de Zoologia da Universidade de São Paulo, Cx. Postal 42694, 04299-970 São Paulo, SP, Brasil \\ Manuscript received on October 31, 2003; accepted for publication on April 4, 2004.
}

\begin{abstract}
The specific concept of G. geckoides was initially ascertained based on a topotypical sample from Salvador, Bahia. Geographic differentiation was studied through the analysis of two meristic characters (tubercles in a paramedian row and fourth toe lamellae) and color pattern of 327 specimens from 23 localities. It is shown that the population from the southernmost locality, Mucugê, is markedly divergent in all characters studied. A Holocene refuge model is proposed to explain the pattern. A decision about the rank to be attributed to the Mucugê population is deferred until more detailed sampling is effected and molecular methods are applied.
\end{abstract}

Key words: speciation, Holocene refuges, lizards: ecology, lizards: systematics.

\section{INTRODUCTION}

The Gymnodactylus geckoides complex has one of the most interesting distributions of all cis-Andean lizards. It occurs in such diversified areas as the semi-arid caatingas of northeastern Brazil, the Central Brazilian cerrados, which are mesic open formations, and the humid Atlantic coast. The elucidation of its evolutionary patterns is of considerable interest. In the present paper I study the geographical differentiation of G. geckoides s. str. in the domain of the caatingas.

\section{LITERATURE}

Spix (1825), in his Species novae lacertarum, described, in the order Lacertae, section Amblyglossae (p. 1), family Geckones (which, in the book, included four species of present Gekkonidae and one of Polychridae), the new genus Gymnodactylus, with only the species geckoides (p. 17, pl. 18:1).

*Member Academia Brasileira de Ciências

E-mail: vanzo@usp.br
Both the description and the figure are very good. The type locality, environs of the city of Bahia (the present Salvador), is satisfactorily explicit, and the animal is still fairly common there.

Fitzinger (1826: 48), in a rather confused note on gekkonid systematics, placed geckoides in his new genus Stenodactylus, together with the present Alsophylax pipiens (Pallas 1811), Asiatic, and his new species $S$. elegans, a synonym of $S$. sthenodactylus Lichtenstein, 1823, North African and Near Eastern. Later (Fitzinger 1843: 43) he still adhered to this concept.

H. Boie (1826: 119), in a review of Spix's book, made a trivial comment on the generic allocation of geckoides, which, for him, should go in Ascalabotes Wagler, an opinion with which Fitzinger (1827: 746) agreed.

Cuvier (1829: 58, reprinted by Duvernoy 1841: 81) maintained Gymnodactylus: "doigts grêles et nus, queue ronde.' Wagler (1830: 144) also maintained the genus and species, but included 
the Australian Phyllurus platurus (White 1790).

Gray (1831: 52) gave G. geckoides a nomen novum, Cyrtodactylus spixii. He mistranslated Spix's original description, taking "dorsum utrinque seriebus 6 longitutinalibus aculeorum... munitum", i.e., dorsum with six series of tubercles on each side ("utrinque") to mean "back with six series of tubercles". Gray's Cyrtodactylus included at least four currently accepted genera (Kluge 1993).

Schinz (1834: 75, pl. 16) reproduced Spix's description and figure under the nomen novum Gecko gymnodactylus.

Wiegmann (1834: 19) dealt with the systematics at the generic level, and proposed a very heterogeneous genus Gymnodactylus, including Asiatic Alsophylax pipiens (Pallas 1811), as well as " $G$. guttulatus Cuvier', which is very probably a misprint of G. guttatus, a synonym of Stenodactylus sthenodactylus Lichtenstein, 1823 (fide Boulenger 1885: 17, Kluge 1993: 62), which occurs in Egypt and the Near East.

Duméril and Bibron (1836: 423) did not see any New World specimen of Gymnodactylus. They suspected Spix's species of being a synonym of Cyrtopodion scaber (Heyden 1827), because Spix (1824) had mistakenly included in his Brazilian list specimens of Mauremys caspica and Malpolon monspessulanum collected in Gibraltar.

Gray (1845) is a very important paper. Initially, he established a detailed diagnosis of the genus. It contains, from the viewpoint of geckoides, a bad mistake: "tail with rings of acute angular spines." It is, however, a historically important diagnosis: it shows how little understood at the time the systematics of the simple-toed geckos was, and the extravagant synonymies that existed at the species level, extending across the world. In his treatment of geckoides proper, Gray (1845: 175) listed a series of supposed synonyms from Africa, Asia and the Mediterranean and, most relevant to the understanding of his concept, cited two specimens he had seen, in the British Museum, from "Shores of the Mediterranean. Presented by J. Miller, Esq.'. These, Dr. Colin McCarthy informs me, are actually Medio- dactylus kotschyi (Steindachner 1870), as already noticed by Boulenger (1885: 29).

In the "Additions and Corrections" to the paper, Gray (1845: 274) described the new species Cubinia darwinii, based on two specimens (respectively from Rio de Janeiro and Salvador), presented by Charles Darwin, certainly collected during the voyage of the "Beagle". That Gray placed his species in Cubinia indicates his misconception of Gymnodactylus.

Steindachner (1867, republished 1870) presented an excellent description of a new species, Gymnodactylus girardi, without type locality, collected during the expedition of the Austrian frigate "Novara". Boulenger (1885: 39) synonymized the species with G. geckoides, in which he was generally followed (e.g., Kluge 1993). I (Vanzolini 1953b: 252) placed it instead into the synonymy of G. darwinii (Gray 1845).

Peters (1877: 411) represents a most regrettably lost opportunity: this great herpetologist saw Spix's type of G. geckoides, which was subsequently lost (Hoogmoed and Gruber 1983: 392), and did not describe it. He only remarked that, being a Mediterranean species, it had probably been introduced in Brazil by maritime traffic. Of some value, he confirmed the type locality, environs of Salvador ("aus der Umgebung von Bahia').

Boulenger (1885: 39-40), besides the data already quoted above, reduced $C$. darwinii to the synonymy of G. geckoides, listing as types "a-b. Hgr. Bahia or Rio Janeiro"'. This led me to believe that the specimens, untagged and initially kept in separate bottles, identified by labels, had somehow gotten mixed in the same bottle, and are no longer individually identifiable. This has been confirmed by Dr. Coli McCarthy (in litt.). Boulenger (1.c.: 40) gave the snout-to-vent length of one of the darwinii types, $37 \mathrm{~mm}$.

Strauch (1887: 51) commented on the allocation of Spix's form to Mediterranean species and concluded, based on the pholidosis of a St. Petersburg specimen from Bahia, that it was actually a Brazilian species. 
Goeldi (1902: 511) made a serious mistake by attributing to Spix the statement of having collected G. geckoides in Rio. Goeldi thought the species to be valid due to it having been collected, after Spix, by Darwin in Salvador and Rio de Janeiro.

Griffin (1917: 307) reported on two specimens from the caatingas of the state of Bahia (Queimadas and Bom Jesus da Lapa), collected by Haseman.

Barbour (1925: 101) described in good detail Gymnodactylus amarali from Engenheiro Dodt, Piauí. He cited Afranio do Amaral as collector. This is not correct: Amaral never was in Piauí. The actual collector was Francisco de Assis Iglesias, a travelling collector employed by Instituto Butantan (Iglesias 1951, Amaral 1923: 99).

Amaral (1933: 57) described Gymnodactylus conspicuus from Vila Nova (now Senhor do Bonfim), Bahia. He later (1934: 189, 1935a: 230) reported the species from Santa Luzia, Paraíba, and Custodia, Pernambuco. I (Vanzolini 1953: 251) reduced it to the synonymy of $G$. geckoides Spix, 1825 . Amaral (1935b :242) reported G. amarali from Cana Brava, Goiás (now in Tocantins).

Amaral (1950: 281) described Gonatodes helgae from the island of São Sebastião, on the coast of S. Paulo. I (Vanzolini 1953: 73) synonymized it with Gymnodactylus darwinii (Gray 1845).

Schmidt and Inger (1951: 450) reported $G$. geckoides from localities in the State of Rio Grande do Norte: Baixa Verde (now João Camara), Ceará Mirim, Extremoz and Natal.

In 1953 I published twice on the genus. In one paper (Vanzolini 1953: 73) I synonymized, as said, Gonatodes helgae Amaral with Gymnodactylus darwinii Gray. In the second paper (Vanzolini 1953) I studied the geographical differentiation of the genus. I recognized that this was a group at the same time with a strong personality (digital morphology, dorsal tubercles, sub-cycloid ventrals) and strong indications of geographical differentiation.

Differentiation was noted on scale counts and dorsal color pattern. Neither the materials at hand nor the statistical methods used permitted an adequate analysis, but I arrived at a provisional scheme, in which three subspecies were recognized:
1. Gymnodactylus g. geckoides Spix, 1825

Rows of dorsal tubercles, 12; tubercles in a paramedian row, 37-46; ventrals, 17-22; lamellae, 16-20; dorsum brown without or with scarce dark marblings, no ocelli; distribution, northeastern Brazil from Salvador north to northern Paraíba; synonym, Gymnodactylus conspicuus Amaral, 1932.

2. Gymnodactylus geckoides darwinii (Gray 1845)

Rows of dorsal tubercles, 12-16; tubercles in a paramedian row, 64-78; ventrals, 13-16; lamellae, 12-16; dorsum brown with more or less distinct marblings; a black U-shaped nuchal band from eye to eye; distribution, eastern Brazil from Espírito Santo to S. Paulo; synonyms: Gymnodactylus girardi Steindachner, 1869; Gonatodes helgae Amaral, 1950.

3. Gymnodactylus geckoides amarali Barbour, 1925

Rows of dorsal tubercles 12-16; tubercles in a paramedian row, 33-43; ventrals 19-24; lamellae, 13-19; dorsum and flanks with irregular rows of black, white-centered ocelli; distribution, Central Brasil (present states of Goiás, Tocantins and Mato Grosso) to Piauí.

I explicitly did not find signs of intergradation between these forms, but considered them subspecies because they were clearly related, allopatric, occurring in areas ecologically very different, but not separated by any impassable barriers (which would favor intergradation). Such was the paradigm of the times.

In a paper on the ecology of lizards in northeastern Brazil, I (Vanzolini 1974), reported on $G$. darwinii from the Atlantic forest in Pernambuco and on G. geckoides from two caatinga localities in the same state.

Vanzolini et al. (1980) described and illustrated G. geckoides from the general area of the caatingas. Williams and Vanzolini (1980), in a paper on Brazilian Anolis, mentioned G. geckoides from the mesic enclave of Arajara, in Ceará. 
Later (Vanzolini 1982), on the occasion of describing a new and very characteristic species, G. guttulatus, from the Serra do Espinhaço (1320$1360 \mathrm{~m}$ ) in Minas Gerais, I returned to the geckoides species group. I commented on the widespread tendency in the 1940's and 1950's to consider allopatry synonymous with subspecies, and reinstated G. darwinii to full species status; I also commented on the need for more work on the relationships between geckoides and amarali.

Freire-Souza (later Freire 1991, congress abstract 1996) reported, for the first time, G. geckoides and $G$. darwinii occurring together in a sand dune environment in Natal, Rio Grande do Norte. This placed beyond doubt the individuality of the two species.

Pellegrino (1998), in an unpublished doctoral thesis on the cytogenetics of Gymnodactylus, concluded that darwinii is a well-defined species, but that the data then available did not permit a decision as to the relationships between geckoides and amarali.

Finally, Freire (1998) studied the geographical differentiation of G. darwinii. She did not use statistical methods, just published tables of the distributions of frequencies of meristic characters, ordered from North to South and remarked that the variation seemed clinal. I have re-analyzed her data, and found out that effectively the variation of the number of tubercles in a longitudinal row is closely related, not to latitude, but to annual mean temperatures; I hope to return to the subject in a coming paper on G. darwinii.

\section{MATERIALS AND METHODS}

I have used 327 specimens from 23 localities, all in this Museum's collection (see Appendix, Map 1 and Gazetteer). My localities cover an area of about $184,000 \mathrm{sq} \mathrm{km}$, approximately $20 \%$ of the area of the morphoclimatic domain of the caatingas.

\section{SEXING}

Sexing small gekkonids by external inspection of the base of the tail implies unavoidable uncertainty. Dissection of the gonads of collection specimens is frequently indecisive, and involves risk of mutilation (ventral counts may become impracticable). Dissection of the base of the tail is usually conclusive, but involves a considerable risk of breakage and should be resorted to only in case of real need. Of course, when the tail is already broken, dissection of the stump, which always contains the short hemipenes, is easy, decisive and riskless, and should be the method of choice.

Fortunately, in the present case we have a way of improving the confidence on the sexing of specimens. by inspection. In 1977 and 1978, Laurie J. Vitt conducted, on behalf of the Brazilian Academy of Sciences, a program of reptilian ecology at Exu, Pernambuco. He collected a fine series of Gymnodactylus and sexed them, by dissection of the gonads, in the field; his data are in our archives. This Exu sample of geckoides affords a good chance of checking routine sexing. I first sexed independently, at random, Vitt's specimens. I went back to the cases of disagreement, sexing them again at random, without reference to Vitt's data. It turned out that (i) specimens $39 \mathrm{~mm} \mathrm{SVL}$ and larger with intact tails can be sexed by inspection, with an error rate of ca. $15 \%$ (mostly females mistaken for males); (ii) some specimens smaller than $39 \mathrm{~mm}$ can be sexed with some degree of certainty, but mostly had better be left as "juveniles". Adult specimens with broken tails can be confidently, as said, sexed by dissection of the stump, and thus the overall uncertainty drops to about $10 \%$. Given that so far no sex differences have been found in meristic characters of Gymnodactylus, the uncertainty is not serious in the analysis of such characters, but should be kept in mind in studies of relative tail length. In the studies carried out on the Exu sample I have used in parallel Vitt's and my sex determinations. The results agree closely. I here adopt Vitt's data. 


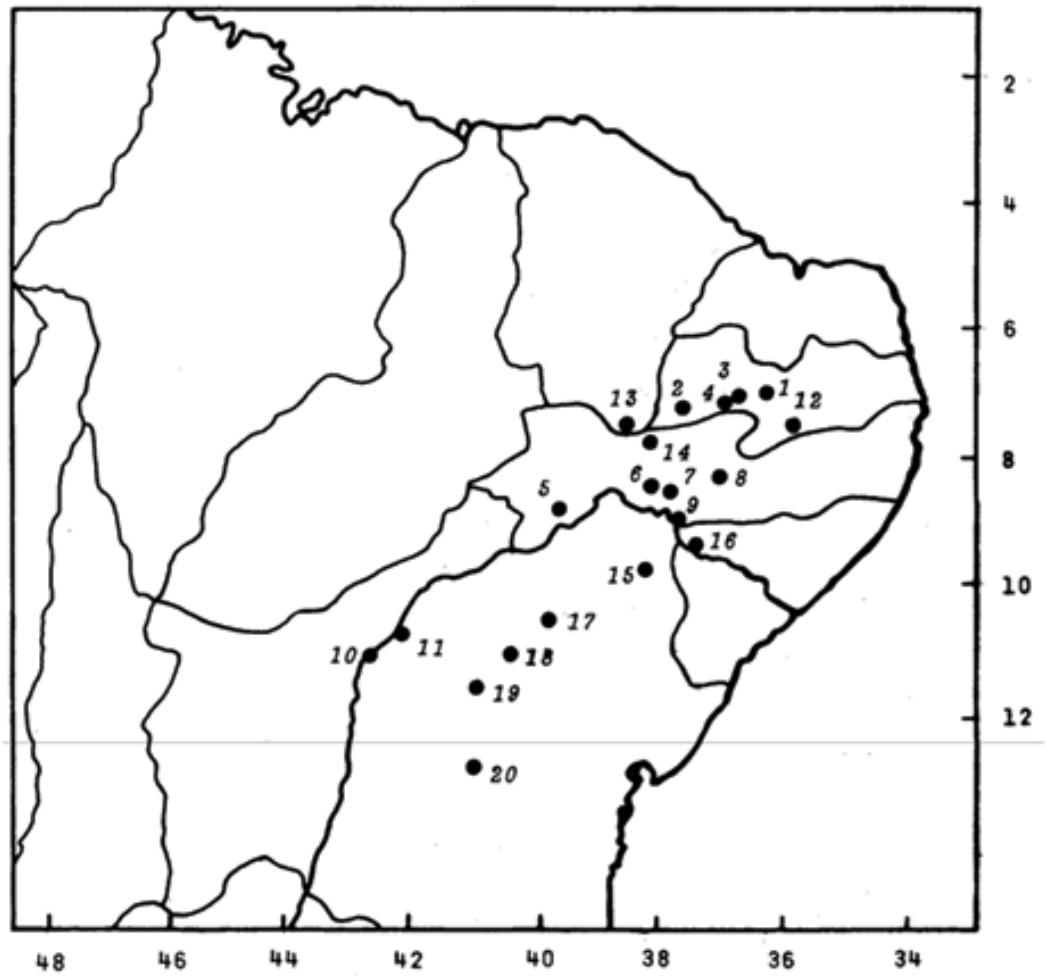

Map 1 - Localities of the samples used in the analysis. 1. Santa Luzia, 2. Piancó, 3. S. José de Espinharas, 4. km 353 Patos-Malta, 5. Encruzilhada, 6. Carnaubeira, 7. Floresta do Navio, 8. Custódia, 9. Paulo Afonso, 10. Barra, 11. Vacaria + Xiquexique, 12. Cabaceiras, 13. Santana do Carirí, 14. Exu, 15. Raso da Catarina, 16. Xingó, 17. Senhor do Bonfim.

\section{Characters}

The quantitative characters studied were: relative tail length (regression on body, i.e., snout-to-vent length), number of tubercle rows transversely counted at midbody, number of tubercles in a paramedian tubercle row, number of rows of ventral scales transversely counted at midbody, number of volar lamellae of the fourth (longest) toe.

Measurements were taken to the nearest millimeter with the specimen adpressed against a steel ruler. Tail length is frequently a delicate measurement to take. Small geckos are best, but infrequently, fixed with extended tails, which, besides much facilitating measurement, insures against breakage and causes no great storage problems. Contrariwise, specimens fixed with bent tails, as practically all in my samples, are at risk during handling, more so in the process of measuring. Stretching, however gently, often leads to breakage and always adds variance to the measurement. This is an ineluctable contingency. Another very serious difficulty stems from the impossibility of evincing breaks in the distal, thinner part of the tail. In numerous cases one has the impression that the measurement being taken is not of a whole tail, but there is no way of ascertaining.

Counting the number of longitudinal rows of tubercles may at times offer difficulties, due to irregularities in the outermost rows. My procedure 
was to count several times the tubercles tangent to an imaginary transverse line and to adopt the mode. The range of the variable is narrow, and the data obtained were consistent, that is, independent counts made by myself tended to agree closely.

Tubercles in a paramedian row: on the middle of the back there is usually a granular, tubercle-less median stripe. The two rows adjacent to this area on either side are by definition the paramedian rows. Both the rows and the stripe may be well or not so well defined. The tubercles are counted from the level of the posterior margins of the thighs (in itself a source of uncertainty) to the foremost aligned tubercle in the row. Along the rows there are enough small irregularities of color and shape to offer the eye a fairly sure lead. Doubts were solved by counting several rows several times and taking the mode. Counts turned out again to be reliable.

Ventrals were counted transversely at approximately midbody; occasional small difficulties were encountered due to the presence on the transition from the belly to the flanks of scales similar in shape to the ventrals but smaller. Examination of adjacent rows dispelled any doubts, but a subjective element (involving in fact never more than one scale) of course remains. Specimens sexed in the field by dissection of the gonads may offer some added uncertainty due to unevenness of the margins of the midventral incision.

Counting infradigital lamellae (the ungual sheath not included) involves also an irremovable subjective decision about what is a properly widened first lamella. In spite of this the counts proved once more to be trustworthy.

\section{Statistical Methods}

All statistical methods used were on purpose elementary and directly related to the nature of the variables. They can be found in any elementary textbook, e.g., Dixon and Massey (1983), Zar (1999), Vanzolini (1993).

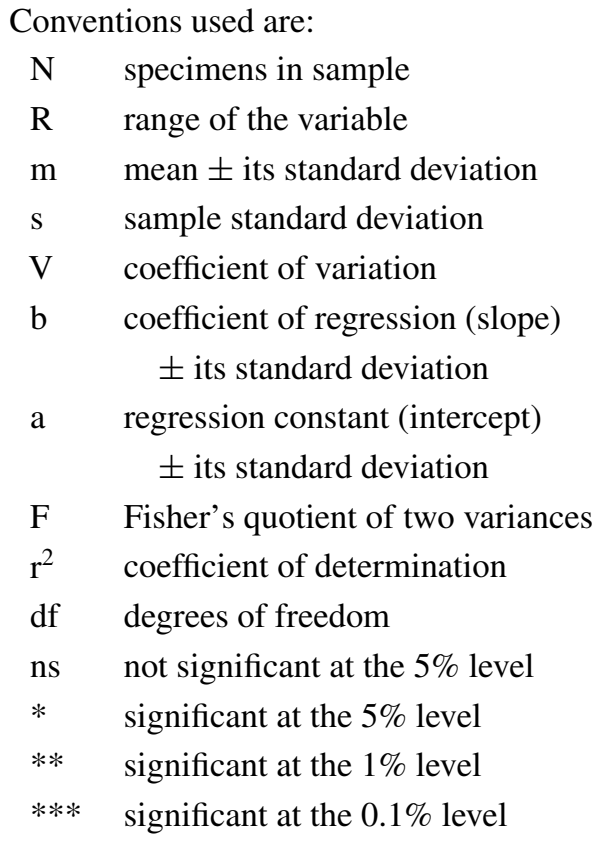

\section{PRELIMINARY CAUTIONS}

Two cautionary steps should always be taken before any statistical analysis is undertaken. First, it should be made sure that all characters studied are statistically independent - otherwise in a final reckoning, two associated characters should be scored as only one. In the present case this precaution turned out to have been essential: two meristic characters are involved in geographic differentiation in parallel ways, but had been shown to be independent. It also should be checked whether juveniles can be freely combined with adults in the analyses, or if they show exceptional values, absent in the adults and thus probably to be eventually pruned by selection. I tested both questions in two very good samples, from Xingó, Alagoas, and Exu, Pernambuco. No exceptional values were found in specimens $39 \mathrm{~mm} \mathrm{SVL}$ (the body length at which sexual dimorphism of the base of the tail becomes evident) or smaller.

In the Exu sample specimens were identified in the field as males, females and unsexed. As there was no difference in body size between sexed and unsexed specimens, I am not calling the latter " ju- 
veniles", just unsexed. As to independence, I computed correlation coefficients for the three pairs of variables, with the following results (degrees of freedom within parentheses):

\begin{tabular}{l|c|c}
\hline & Xingó & Exu \\
\hline $\begin{array}{l}\text { Ventrals } \\
\times \text { tubercles }\end{array}$ & $0.0188(12) \mathrm{ns}$ & $0.0600(83) \mathrm{ns}$ \\
\hline $\begin{array}{l}\text { Lamellae } \\
\times \text { tubercles }\end{array}$ & $0.0432(13) \mathrm{ns}$ & $0.3280(83) \mathrm{ns}$ \\
\hline $\begin{array}{l}\text { Lamellae } \\
\times \text { ventrals }\end{array}$ & $0.1654(14) \mathrm{ns}$ & $0.0753(83) \mathrm{ns}$ \\
\hline
\end{tabular}

The Exu samples (186 specimens, of which 64 with intact tails) afforded also an opportunity of testing the presence of sex dimorphism. The MannWhitney test showed that females have on the average longer bodies $(\mathrm{z}=2.750 * *)$. In scale counts (Table IV) there is homogeneity. Especially welcome is the opportunity to study relative tail length (Table III, Graph 1). The coefficients of determination go from good (0.8897) to very good (0.9626) and there is homogeneity among the three groups (males, females and unsexed). I feel thus justified in generalizing the procedure and lumping together all specimens of the samples whose small numbers do not permit the respective comparisons.

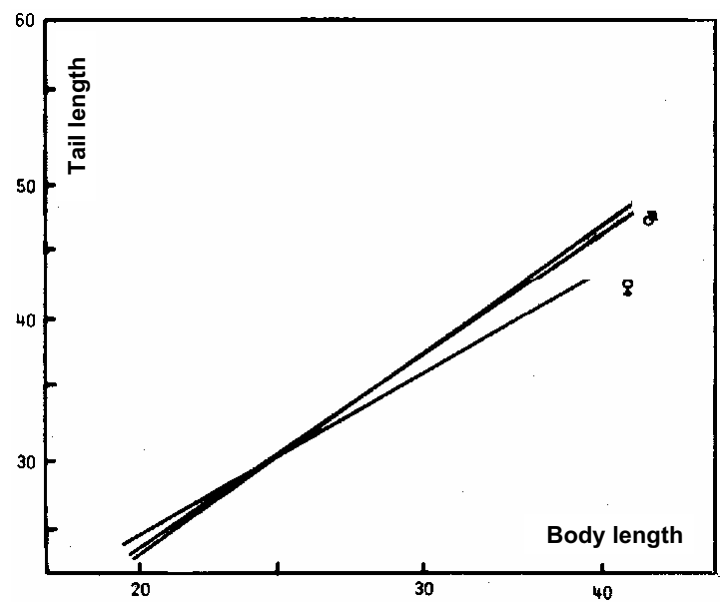

Graph 1 - Gymnodactylus geckoides, Exu, regression of tail length on body length.

\section{THE SALVADOR SAMPLE}

G. geckoides, in the current concept, has an extensive geographic distribution, with commensurate variability; a topotypical sample from Salvador, Bahia, has been fundamental in settling the strict concept of the species. It is fortunate that we have also from Salvador a good sample of the closely related $G$. darwinii (Gray 1845) and that the concept can be reinforced by comparison.

\section{Pholidosis And Color Pattern}

In the context of the systematics of simple-toed geckos, the following suite of characters characterizes topotypical G. geckoides:

- Members pentadactyl, digits not dilated, not fringed (thus Gymnodactylus, "naked finger'), with simple volar lamellae; distal phalanges upturned; all digits clawed, the claws between two scales; plantar surface uniformly granular.

- Dorsal lepidosis heterogeneous, with more or less well aligned keeled tubercles on a background of small granules; ventral scales subcycloid, smooth; caudal scales lanceolate, proximally raised, the midventral row widened.

- Pupil vertically elliptic; superciliary flap reduced to a granular rim, with 2-3 small flat scales anteriorly. Ear opening very small.

- Top of snout coarsely granular; rostral high, depressed, incised in the middle; nostril between the rostral, a corner of the first labial and one supranasal, in contact with its fellow or separated from it by 1-3 granules. Top of head with fine granules and numerous small, button-like round tubercles.

- Six supralabials to the middle of the eye.

- Anterior edge of arm and forearm, dorsal surface of arm and hand with scales almost as large as the ventrals, imbricate, proximally keeled and sub-mucronate; remainder of forelimb granular. 
- Thigh and ventral aspect of leg with scales similar to the ventrals; dorsal surface of leg with small conical close-packed scales.

- Dorsum dark brown, uniform or with inconspicuous black marblings (further materials showed considerable variation in dorsal color pattern, ill-defined ocelli or diffuse whitish markings being frequent: Figs. 1,2).
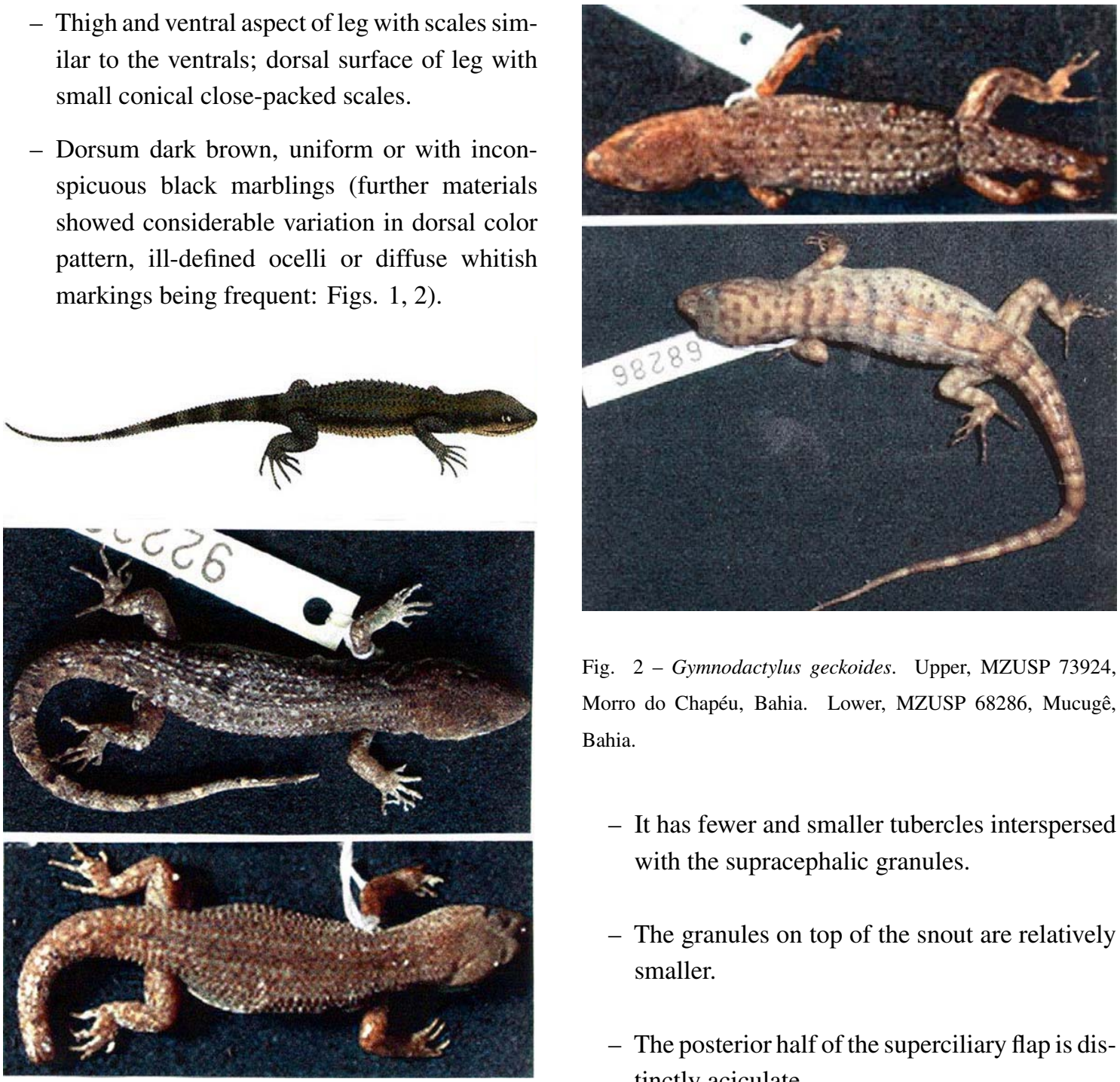

Fig. 2 - Gymnodactylus geckoides. Upper, MZUSP 73924, Morro do Chapéu, Bahia. Lower, MZUSP 68286, Mucugê, Bahia.

- It has fewer and smaller tubercles interspersed with the supracephalic granules.

- The granules on top of the snout are relatively smaller.

- The posterior half of the superciliary flap is distinctly aciculate.

Fig. 1 - Gymnodactylys geckoides. Upper, Holotype, from Spix (1825: pl. 18, 1). Middle, MZUSP 92233, Salvador, Bahia. Lower, MZUSP 48021, Exu, Pernambuco.

- Ventral surfaces whitish, with scattered dark punctuations, especially on the flanks, preanal region and thighs.

- Tail dorsally brown, with black and dark yellow rings, more distinct distally; ventral scales whitish, with dark markings on the sutures.

G. darwinii from Salvador broadly (i.e. at the generic level) agrees with these characters, with the following major differences:

- The supranasals are usually in contact.

- There are only five supralabials to the middle of the eye.

- There is a conspicuous row of enlarged granules on the thenar margin of the plantar surface, in line with the hallux.

- The dorsum is grayish-brown with definite transverse black marblings. There is a characteristic black, frequently white-bordered nuchal band, from eye to eye. 
TABLE I

Gymnodactylus, Salvador, rows of tubercles.

\begin{tabular}{c|c|c}
\hline & darwinii & geckoides \\
\hline 12 & 2 & 7 \\
13 & 2 & \\
14 & 16 & \\
15 & 2 & \\
16 & 6 & \\
& 28 & 7 \\
\hline
\end{tabular}

\section{Scale Counts}

Some characters sharply differ between the two samples (Tables I and II) and are paramount in tracking the species away from the area of sympatry.

A first and fundamental difference concerns the dorsal tubercles, both in arrangement and number. They are much more regular in darwinii. As to the number of rows transversely counted, all geckoides (Table I) have 12, and darwinii varies from 12 to 16,12 being rare: the modal count $(16 / 28$, or $57 \%)$ is 14 .

The number of tubercles in a paramedian row (Table II) differs widely: there is no superimposition between the two distributions of frequencies. The same can be said of the number of ventrals. In the number of fourth toe lamellae there is a short superimposition, but the difference is again very wide.

A comparison of relative tail lengths presented some difficulties. Our Salvador geckoides sample contains only 3 specimens (one juvenile, one male and one female) with intact tails. The sample of darwinii, on the contrary, has 6 young, 11 males and 6 females amenable to analysis. I computed the regressions for the last three groups (Table III). The regression of the juveniles was excellent: $r^{2}=0.9712$. Those of males and females did not reach the level of significance, I think due to short ranges of body length. Combining males and females, a siginificant regression was obtained, with a mediocre fit $\left(\mathrm{r}^{2}\right.$ $=0.6563)$. This joint regression, however, did not differ significantly from that for juveniles: $t$ for the difference between the coefficients of regression was 0.715 (19 df, ns), for that between intercepts 0.990 ( $20 \mathrm{df}, \mathrm{ns}$ ). The regressions could thus be combined, and the resulting one, with improved ranges now, turned out very good $\left(r^{2}=0.9355\right)$. This allowed me to attempt a test of the differences between the observed tail length of individual geckoides specimens and the values computed for the same body length of darwinii (Graph 2). Of the three values of $t$ obtained, one (2.139 ns) was not significant, but two, $6.807^{* * *}$ and $6.002^{* * *}$, concerning the two larger specimens, were highly significant. This seems to indicate that darwinii has a relatively longer tail than geckoides.

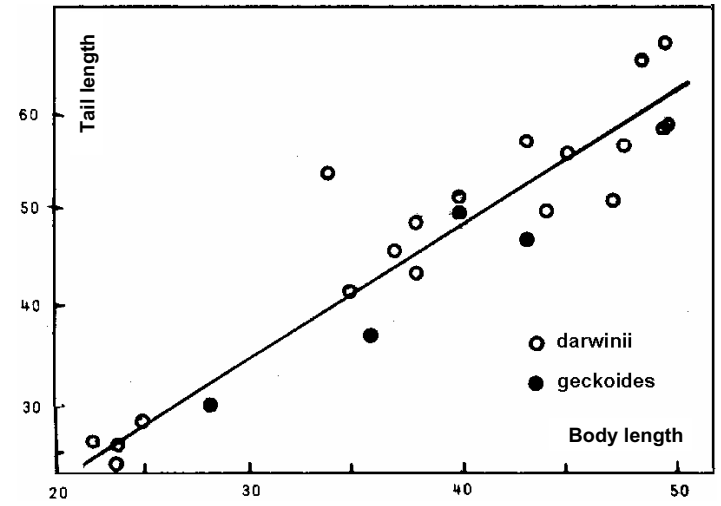

Graph 2 - Gymnodactylus geckoides and G. darwinii, Salvador, Bahia, regression of tail length on body length.

At any rate, scale counts and color pattern afford easy and unambiguous identification of the two species.

\section{GEOGRAPHICAL DIFFERENTIATION OF G. geckoides}

At this stage I apply the name G. geckoides to specimens agreeing with the Salvador sample in general pholidotic characters, and especially in having 12 rows of tubercles.

A look at Map 1 or at the list of specimens (Appendix) will clearly show that G. geckoides is essentially a lizard of the morphoclimatic domain of the caatingas (Ab'Sáber 1977b, Velloso et al. 2002). Salvador, a coastal locality in a complex ecological 
TABLE II

Gymnodactylus, Salvador. Statistics of the distributions of frequencies of scale counts.

\begin{tabular}{l|c|c|c|c|c|c|c}
\hline & $\mathrm{N}$ & $\mathrm{R}$ & $\mathrm{m}$ & $\mathrm{s}$ & $\mathrm{V}$ & $\mathrm{t}$ \\
\hline Rows of tubercles \\
\hline geckoides & 7 & 12 & & & & \\
\hline darwinii & 28 & $12-16$ & $14.3 \pm 0.21$ & 1.1 & 7.8 & \\
\hline Tubercles in a paramedian row \\
\hline geckoides & 7 & $42-49$ & $41.9 \pm 0.88$ & 0.34 & 5.1 & \\
\hline darwinii & 24 & $53-66$ & $60.0 \pm 0.67$ & 3.30 & 5.5 & \\
\hline Ventrals & 7 & $20-24$ & $22.0 \pm 0.62$ & 1.63 & 7.4 & \\
\hline geckoides & 7 & $14-19$ & $16.5 \pm 0.22$ & 1.20 & 7.3 & \\
\hline darwinii & 30 & 14 & \\
\hline Lamellae & 7 & $17-19$ & $18.0 \pm 0.31$ & 0.82 & 4.5 & \\
\hline geckoides & 7 & & & & $4.550^{* * *}$ \\
\hline
\end{tabular}

TABLE III

Gymnodactylus, statistics of the regression of tail length on body length.

\begin{tabular}{|c|c|c|c|c|c|c|c|}
\hline & $\mathrm{N}$ & $\mathrm{R}(\mathrm{x})$ & $\mathrm{R}(\mathrm{y})$ & $\mathrm{b}$ & $\mathrm{a}$ & $\mathrm{F}$ & $\mathrm{r}^{2}$ \\
\hline \multicolumn{8}{|c|}{ darwinii, Salvador } \\
\hline juveniles & 6 & $23-35$ & $25-42$ & $0.43 \pm 0.123$ & $-8.33 \pm 2.824 * * *$ & $135.074 * * *$ & 0.9712 \\
\hline$\sigma^{x}$ & 11 & $43-50$ & $57-68$ & & & $4.140 \mathrm{~ns}$ & \\
\hline q & 6 & $37-40$ & $46-51$ & & & $2.640 \mathrm{~ns}$ & \\
\hline$q^{n}$ & 17 & $37-50$ & $46-68$ & $1.15 \pm 0.255$ & $3.75 \pm 2.143 \mathrm{~ns}$ & $28.645 * * *$ & 0.6563 \\
\hline $\mathrm{j} \phi^{7}$ & 23 & $23-50$ & $25-68$ & $1.37 \pm 0.078$ & $-5.98 \pm 2.874 \mathrm{~ns}$ & $304.654 * * *$ & 0.9355 \\
\hline \multicolumn{8}{|c|}{ geckoides, Exu } \\
\hline unsexed & 9 & $20-41$ & $24-50$ & $1.44 \pm 0.108$ & $-5.33 \pm 4.4478 \mathrm{~ns}$ & $179.970 * * *$ & 0.9626 \\
\hline$\sigma^{\pi}$ & 28 & $19-42$ & $25-55$ & $1.33 \pm 0.092$ & $-1.92 \pm 1.959 \mathrm{~ns}$ & $209.724 * * *$ & 0.8897 \\
\hline q & 27 & $20-42$ & $25-52$ & $1.15 \pm 0.077$ & $1.97 \pm 1.779 \mathrm{~ns}$ & $219.585 * * *$ & 0.8978 \\
\hline all & 64 & $19-42$ & $25-55$ & $1.27 \pm 0.055$ & $-0.82 \pm 1.294 \mathrm{~ns}$ & $528.670 * * *$ & 0.8950 \\
\hline \multicolumn{8}{|c|}{ geckoides, all samples } \\
\hline $\mathrm{j} \phi^{\mathrm{r}}$ & 39 & $23-51$ & $25-70$ & $1.27 \pm 0.100$ & $-3.58 \pm 1.579 *$ & $161.529 * * *$ & 0.8136 \\
\hline
\end{tabular}

setting, is the only exception. In this phase of the analysis Salvador will be left out; materials at hand are not sufficient for analysis. Thus, only samples from the morphoclimatic domain of the caatingas will be analyzed. The general strategy employed has been discussed in Vanzolini (2002).

I have from the area (Map 1) 12 geographical samples amenable to statistical treatment. These are either single - locality samples, or assemblages of localities reasonably close geographically (at most 
a few tens of kilometers apart), at approximately the same elevation and topography, and ecologically homogeneous. These are (simplified coordinates within parentheses):

1. "Paraíba" (centroid 0657, 3726), 10 specimens from Santa Luzia, Piancó, São José de Espinharas and $\mathrm{km} 353$ of the road from Patos to Malta.

2. Cabaceiras $(0730,3617)$, single locality, 6 specimens, somewhat damaged, useful only for the study of fourth toe lamellae.

3. Santana do Carirí $(0711,3944), 5$ specimens.

4. Exu (031, 3843), 186 specimens. I consider this an unimprovable sample, as good a representation as may be wished of a geographical area. It was assembled during two years; Laurie Vitt, the collector, recorded the actual collecting sites relative to Exu, so it was possible to draw a polygon enclosing all the localities and to measure its area, ca. $230 \mathrm{sq} . \mathrm{km}$, or the area of circle with radius ca. $8.5 \mathrm{~km}$ - in the interior of Brazil a masterpiece of homogeneity for such a large sample. As already mentioned, Vitt sexed his specimens in the field by dissection, which afforded a valuable control of the difficult operation of sexing in the laboratory. The actual centroid of the area falls very close $(2.5 \mathrm{~km})$ to the city of Exu, so I am using the city's coordinates.

5. "Sertão de Pernambuco" (centroid 0842, 3839), 8 specimens from Encruzilhada, Carnaubeira, Floresta do Navio, Custódia and Paulo Afonso.

6. Raso da Catarina (0940, 3840), 8 specimens.

7. Xingó $(0924,3758)$, Xingó proper plus its suburb Piranhas Nova, 19 specimens.

8. Senhor do Bonfim (1027, 4011), 5 specimens.

9. "São Francisco" (centroid 1050, 4248), 9 specimens from Barra, Vacaria and Xiquexique.
10. Caatinga do Moura $(1058,4045), 28$ specimens.

11. Morro do Chapéu (1133, 4109), 23 specimens.

12. Mucugê (1300, 4123), 7 specimens.

The statistics of the distributions of frequencies of the three scale counts are shown in Tables V, VII and IX. A fair amount of geographical variation is noticeable on inspection. I studied this by applying successively analysis of variance and Tukey's test for the means. The analyses of variance showed highly significant values for tubercles and lamellae, moderately so for ventrals.

\begin{tabular}{l|c|c}
\hline & $\mathrm{F}$ & $\mathrm{df}$ \\
\hline Tubercles & $18.802 * * *$ & $9: 220$ \\
\hline Ventrals & $2.771 * *$ & $9: 229$ \\
\hline Lamellae & $11.962 * * *$ & $11: 280$ \\
\hline
\end{tabular}

Relative tail length is, as said, a difficult matter in the case of lizards with very fragile and finepointed tails. My samples do not permit an adequate analysis.

\section{Ecological CoRrelations}

As remarked above, Freire (1998) discovered in $G$. darwinii a latitudinal cline which, on further analysis, revealed a close statistical relationship between annual mean temperatures and the number of tubercles in a paramedian row. Thus, although the narrow span of latitudes (a little over 6 degrees) covered by my samples offered little promise, I started my investigation by plotting the scale counts against latitude. Tubercles and ventrals showed no relationship, but fourth toe lamellae showed a striking regression, with the outstanding exception of the sample from Xingó (Graph 3). Of course, latitude as such is not an ecological factor; it only offers a relatively effortless first approach to the problem. The two obvious environmental variables conceivably related to latitude, are, in this case, beyond doubt, temperature and precipitation. 
TABLE IV

Gymnodactylus geckoides, Exu, scale counts, statistics of the distributions of frequencies.

\begin{tabular}{|c|c|c|c|c|c|c|}
\hline & $\mathrm{N}$ & $\mathrm{R}$ & $\mathrm{m}$ & $\mathrm{s}$ & $\mathrm{V}$ & $\mathrm{t}$ \\
\hline \multicolumn{7}{|c|}{ Tubercles in a paramedian row } \\
\hline uns & 9 & $39-48$ & $43.7 \pm 0.85$ & 2.5 & 5.8 & $0.970 \mathrm{~ns}$ \\
\hline \multirow{2}{*}{$\sigma^{\pi}$} & 47 & $39-49$ & $44.6 \pm 0.35$ & 2.4 & 5.4 & \\
\hline & & & & & & $0.238 \mathrm{~ns}$ \\
\hline q & 74 & $37-51$ & $44.5 \pm 0.32$ & 2.8 & 6.2 & \\
\hline all & 130 & $37-51$ & $44.5 \pm 0.23$ & 2.6 & 3.9 & \\
\hline \multicolumn{7}{|c|}{ Ventrals } \\
\hline uns & 10 & $19-22$ & $20.8 \pm 0.29$ & 0.9 & 4.4 & $0.201 \mathrm{~ns}$ \\
\hline \multirow[t]{2}{*}{$\sigma^{x}$} & 52 & $18-24$ & $20.7 \pm 0.15$ & 1.1 & 5.2 & \\
\hline & & & & & & $0.097 \mathrm{~ns}$ \\
\hline q & 75 & $18-24$ & $20.7 \pm 0.15$ & 1.3 & 6.5 & \\
\hline all & 137 & $18-24$ & $20.7 \pm 0.10$ & 1.2 & 5.8 & \\
\hline \multicolumn{7}{|c|}{ Fourth toe lamellae } \\
\hline uns & 11 & $14-17$ & $15.4 \pm 0.28$ & 0.9 & 6.0 & $0.226 \mathrm{~ns}$ \\
\hline \multirow[t]{2}{*}{$\sigma^{x}$} & 64 & $13-19$ & $15.3 \pm 0.17$ & 1.4 & 9.0 & \\
\hline & & & & & & $1.124 \mathrm{~ns}$ \\
\hline O & 93 & $13-18$ & $15.5 \pm 0.13$ & 1.2 & 7.9 & \\
\hline all & 168 & $13-19$ & $15.4 \pm 0.098$ & 1.3 & 8.2 & \\
\hline
\end{tabular}

TABLE V

Gymnodactylus geckoides, tubercles in a paramedian row, statistics of the distributions of frequencies.

\begin{tabular}{l|c|c|c|c|c}
\hline & $\mathrm{N}$ & $\mathrm{R}$ & $\mathrm{m}(\mathrm{x})$ & $\mathrm{s}$ & $\mathrm{V}$ \\
\hline Paraíba & 7 & $44-49$ & $47.0 \pm 0.62$ & 1.6 & 3.5 \\
\hline Santana do Carirí & 2 & $53-54$ & 53.5 & & \\
\hline Exu & 130 & $37-51$ & $44.5 \pm 0.23$ & 2.6 & 3.9 \\
\hline Sertão de Pernambuco & 10 & $43-52$ & $46.8 \pm 0.88$ & 2.8 & 5.9 \\
\hline Raso da Catarina & 8 & $41-47$ & $44.3 \pm 0.73$ & 2.1 & 4.6 \\
\hline Xingó & 16 & $42-57$ & $48.8 \pm 1.11$ & 4.4 & 9.1 \\
\hline Senhor do Bonfim & 4 & $41-49$ & $44.8 \pm 1.65$ & 3.3 & 7.4 \\
\hline S. Francisco & 9 & $44-51$ & $46.6 \pm 0.80$ & 2.4 & 5.2 \\
\hline Caatinga do Moura & 24 & $39-48$ & $43.8 \pm 0.48$ & 2.4 & 5.4 \\
\hline Morro do Chapéu & 17 & $36-45$ & $40.5 \pm 0.79$ & 3.3 & 8.1 \\
\hline Mucugê & 5 & $32-36$ & $33.6 \pm 0.68$ & 1.5 & 4.5 \\
\hline
\end{tabular}


TABLE VI

Gymnodactylus geckoides, tubercles in a paramedian row, Tukey's test.

\begin{tabular}{l|c|c}
\hline & $\mathrm{N}$ & $\mathrm{m}(\mathrm{x})$ \\
\hline 1. Mucugê & 5 & 33.6 \\
2. Morro do Chapéu & 17 & 40.5 \\
3. Caatinga do Moura & 24 & 43.8 \\
4. Raso da Catarina & 8 & 44.3 \\
5. Exu & 130 & 44.5 \\
6. Senhor do Bonfim & 4 & 44.8 \\
7. S. Francisco & 9 & 46.6 \\
8. Sertão de Pernambuco & 10 & 46.8 \\
9. Paraíba & 7 & 47.0 \\
10. Xingó & 16 & 48.8 \\
\hline
\end{tabular}

TABLE VII

Gymnodactylus geckoides, ventral scales, statistics of the distributions of frequencies.

\begin{tabular}{l|c|c|c|c|c}
\hline & $\mathrm{N}$ & $\mathrm{R}$ & $\mathrm{m}(\mathrm{x})$ & $\mathrm{s}$ & $\mathrm{V}$ \\
\hline Paraíba & 5 & $19-21$ & $20.4 \pm 0.40$ & 0.9 & 4.4 \\
\hline Santana do Carirí & 3 & $21-22$ & 21.3 & - & - \\
\hline Exu & 137 & $18-24$ & $20.7 \pm 0.10$ & 1.2 & 5.8 \\
\hline Sertão de Pernambuco & 12 & $20-23$ & $21.1 \pm 0.34$ & 1.2 & 5.5 \\
\hline Raso da Catarina & 10 & $19-24$ & $21.2 \pm 0.53$ & 1.7 & 8.0 \\
\hline Xingó & 18 & $19-24$ & $21.7 \pm 0.44$ & 1.9 & 8.5 \\
\hline Senhor do Bonfim & 4 & $20-22$ & $21.0 \pm 0.41$ & 0.8 & 3.9 \\
\hline S. Francisco & 9 & $20-22$ & $20.8 \pm 0.32$ & 1.0 & 4.5 \\
\hline Caatinga do Moura & 26 & $19-23$ & $21.0 \pm 0.24$ & 1.2 & 5.9 \\
\hline Morro do Chapéu & 14 & $20-24$ & $22.2 \pm 0.39$ & 1.5 & 6.7 \\
\hline Mucugê & 4 & $17-22$ & $20.3 \pm 1.18$ & 2.4 & 11.7 \\
\hline
\end{tabular}

I found in the literature no individual data on temperature and rainfall of all my localities, but, by strategically using the available information, it was possible to assemble workable data, especially keeping in mind that the purpose of the investigation is not to establish accurate equations relating the biological variables to temperature and rainfall, but simply to evince the eventual relevance of the abiotic variables to the process of geographical differentiation.
Annual mean temperature. Temperatures in the domain of the caatingas are high and do not vary much in space or time. They are considered of secondary ecological relevance, and do not receive much attention in the literature. Direct temperature data were available for only three of my twelve samples, all presented as collateral information in rainfall tables. There are published equations (multiple regression) aimed at calculating temperatures based on altitude, latitude and longitude (Bahia 1998, Azevedo and Moreira 1981). I checked these 
TABLE VIII

Gymnodactylus geckoides, ventral scales, Tukey's test.

\begin{tabular}{l|c|c|}
\hline & $\mathrm{m}(\mathrm{x})$ & $\mathrm{N}$ \\
\hline 1. Mucugê & 20.3 & 4 \\
2. Paraíba & 20.4 & 5 \\
3. Exu & 20.7 & 137 \\
4. S. Francisco & 20.8 & 9 \\
5. Caatinga do Moura & 21.0 & 26 \\
6. Senhor do Bonfim & 21.0 & 4 \\
7. Sertão de Pernambuco & 21.1 & 12 \\
8. Raso da Catarina & 21.2 & 10 \\
9. Xingó & 21.7 & 18 \\
10. Morro do Chapéu & 22.2 & 14 \\
\hline
\end{tabular}

TABLE IX

Gymnodactylus geckoides, fourth toe lamellae, statistics of the distributions of frequencies.

\begin{tabular}{l|c|c|c|c|c}
\hline & $\mathrm{N}$ & $\mathrm{R}$ & $\mathrm{m}(\mathrm{x})$ & $\mathrm{s}$ & $\mathrm{V}$ \\
\hline Paraíba & 10 & $14-16$ & $15.0 \pm 0.30$ & 0.9 & 6.3 \\
\hline Santana do Carirí & 5 & $14-16$ & $15.0 \pm 0.32$ & 0.7 & 4.7 \\
\hline Cabaceiras & 6 & $14-16$ & $14.5 \pm 0.34$ & 0.8 & 5.8 \\
\hline Exu & 168 & $13-19$ & $15.4 \pm 0.10$ & 1.3 & 8.2 \\
\hline Sertão de Pernambuco & 12 & $13-18$ & $15.5 \pm 0.36$ & 1.2 & 8.0 \\
\hline Xingó & 19 & $13-17$ & $14.8 \pm 0.21$ & 0.9 & 6.1 \\
\hline Raso da Catarina & 10 & $15-17$ & $16.2 \pm 0.25$ & 0.8 & 4.9 \\
\hline Senhor do Bonfim & 5 & $16-18$ & $17.0 \pm 0.45$ & 1.0 & 5.9 \\
\hline S. Francisco & 7 & $15-18$ & $16.4 \pm 0.37$ & 1.0 & 5.9 \\
\hline Caatinga do Moura & 24 & $16-19$ & $16.7 \pm 0.14$ & 0.7 & 4.1 \\
\hline Morro do Chapéu & 19 & $16-18$ & $17.1 \pm 0.14$ & 0.6 & 3.6 \\
\hline Mucugê & 7 & $17-20$ & $18.4 \pm 0.43$ & 1.1 & 6.2 \\
\hline
\end{tabular}

equations against the data from which they were obtained and found poor agreement. A cursory investigation revealed that the regression coefficients relative to latitude and longitude did not (in the geographical space of my samples) reach significance. It was apparent that (always within the pertinent geographical space) the best predictor of annual mean temperature was altitude. I obtained the equation

$$
y^{\prime}=27.15-0.0073 * \text { altitude }
$$

with a coefficient of determination of 0.7740 , quite reasonable in the circumstances. A check of computed temperatures against original data afforded deviations between 0 and $6 \%$, no bias being apparent, so I subsequently adopted this equation. I computed (Table XI) the temperatures of the localities for which no direct data were available, and regressed the scale counts on the whole.

The regression of the number of tubercles in a longitudinal row (Graph 4, Table XII) on mean an- 
TABLE X

Gymnodactylus geckoides, fourth toe lamellae, Tukey's test.

\begin{tabular}{|c|c|c|}
\hline & $\mathrm{N}$ & $\mathrm{m}(\mathrm{x})$ \\
\hline 1. Cabaceiras & 6 & 14.5 \\
\hline 2. Xingó & 18 & 14.8 \\
\hline 3. Paraíba & 10 & 15.0 \\
\hline 4. Santana do Carirí & 5 & 15.0 \\
\hline 5. Exu & 168 & 15.4 \\
\hline 6. Sertão de Pernambuco & 12 & 15.5 \\
\hline 7. Raso da Catarina & 10 & 16.2 \\
\hline 8. S. Francisco & 7 & 16.4 \\
\hline 9. Caatinga do Moura & 24 & 16.7 \\
\hline 10. Senhor do Bonfim & 5 & 17.0 \\
\hline 11. Morro do Chapéu & 19 & 17.1 \\
\hline 12. Mucugê & 7 & 18.4 \\
\hline
\end{tabular}

TABLE XI

Gymnodactylus geckoides, data for ecological correlations.

\begin{tabular}{l|c|c|c|c|c|c|c}
\hline \multirow{2}{*}{ Sample } & \multicolumn{2}{|c|}{ Latitude } & Rainfall & Temp. & Tuberc. & Ventr. & Lam. \\
\cline { 2 - 7 } & geogr. & decim. & & & & & \\
\hline Paraíba & 0657 & 6.95 & $617 *$ & $25.2 * *$ & 47.0 & 20.4 & 15.0 \\
\hline Santana do Carirí & 0711 & 7.18 & 750 & $23.6 * *$ & - & - & 15.0 \\
\hline Cabaceiras & 0730 & 7.50 & $390^{*}$ & $24.3 * *$ & - & - & 14.5 \\
\hline Exu & 0731 & 7.52 & 826 & $23.4 * *$ & 44.5 & 20.7 & 15.4 \\
\hline Sertão de Pernambuco & 0842 & 8.70 & $427 *$ & $25.6 * *$ & 46.8 & 21.1 & 15.5 \\
\hline Xingó & 0924 & 9.40 & $603 *$ & $26.7 * *$ & 48.8 & 21.7 & 14.8 \\
\hline Raso da Catarina & 0940 & 9.67 & $408 *$ & $24.2 * *$ & 44.3 & 21.2 & 16.2 \\
\hline Senhor do Bonfim & 1027 & 10.45 & 708 & 23.5 & 44.8 & 21.0 & 17.0 \\
\hline S. Francisco & 1050 & 10.83 & $720 *$ & $23.7 * *$ & 46.6 & 20.8 & 16.4 \\
\hline Caatinga do Moura & 1058 & 10.97 & $759 *$ & $22.0 * *$ & 43.8. & 21.0 & 16.7 \\
\hline Morro do Chapéu & 1133 & 11.55 & 801 & 19.7 & 40.5 & 22.2 & 17.1 \\
\hline Mucugê & 1300 & 13.00 & 961 & 19.9 & 33.6 & 20.3 & 18.4 \\
\hline
\end{tabular}

*average of neighboring localities at approximately the same altitude. **alculated by means of the equation linking temperature and altitude.

nual temperature is quite good, with one exception: Mucugê stands out. The ten remaining samples afforded a coefficient of determination of 0.8946 . In the case of lamellae, two samples deviate, Cabaceiras and S. Francisco; the remainder afford a good regression (Table XII).
Rainfall. Given the importance of water in the everyday life of the caatingas, where droughts are frequent and severe, there are in the literature relatively abundant data on rainfall (Bahia 1998, 1999, Nimer 1979). I had direct data for four single-locality samples; for the others it was easy to obtain averages of 
TABLE XII

Gymnodactylus geckoides, ecological regressions.

\begin{tabular}{|c|c|c|c|c|c|c|}
\hline $\mathrm{N}$ & $\mathrm{R}(\mathrm{x})$ & $\mathrm{R}(\mathrm{y})$ & $\mathrm{b}$ & $\mathrm{a}$ & $\mathrm{F}$ & $r^{2}$ \\
\hline \multicolumn{7}{|c|}{ Rainfall } \\
\hline 12 & $19.9-26.0$ & $390-961$ & $2.044 \mathrm{~ns}$ & & & \\
\hline \multicolumn{7}{|c|}{ Tubercles } \\
\hline 10 & $6.95-13.00$ & $33.6-48.8$ & & & $5.316 \mathrm{~ns}$ & \\
\hline \multicolumn{7}{|c|}{$\times$ temperature } \\
\hline 9 & $19.9-26.7$ & $33.6-48.8$ & $1.10 \pm 0.143$ & $19.0 \pm 1.06 * * *$ & $59.537 * * *$ & 0.8946 \\
\hline \multicolumn{7}{|c|}{$\times$ rainfall } \\
\hline 9 & $408-961$ & $33.6-48.8$ & $-0.019 \pm 0.0074$ & $56.8 \pm 1.54 * * *$ & $6.253 *$ & 0.4718 \\
\hline \multicolumn{7}{|c|}{ Lamellae } \\
\hline 11 & $6.95-13.00$ & $14.5-18.4$ & $0.54 \pm 0.0538$ & $11.0 \pm 0.39 * * *$ & $100.352 * * *$ & 0.9177 \\
\hline \multicolumn{7}{|c|}{$\times$ temperature (Cabaceiras and S. Francisco excluded) } \\
\hline 10 & $19.9-25.7$ & $14.8-18.4$ & $-0.621 \pm 0.0852$ & $30.8 \pm 0.56 * * *$ & $53.054 * * *$ & 0.8690 \\
\hline \multicolumn{7}{|c|}{$\times$ rainfall } \\
\hline 12 & $390-961$ & $14.5-18.4$ & $0.0044 \pm 0.00173$ & $13.1 \pm 0.35 * * *$ & $6.426^{*}$ & 0.3912 \\
\hline
\end{tabular}

*average of neighboring localities at approximately the same altitude. **calculated by means of the equation linking temperature and altitude.

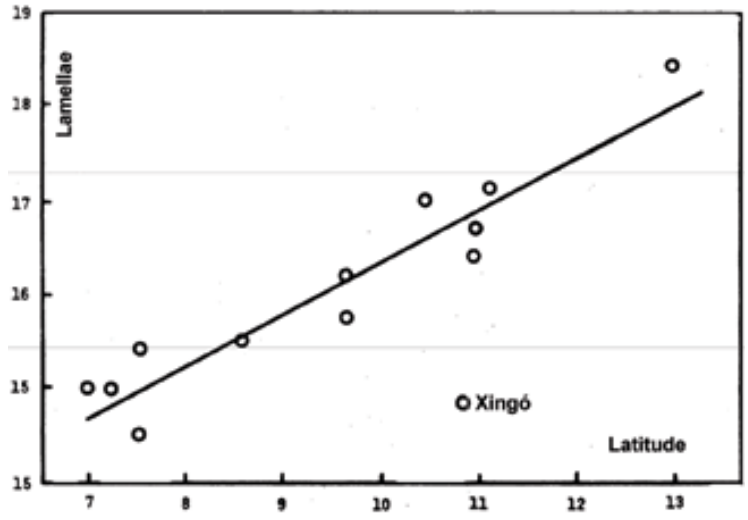

Graph 3 - Gymnodactylus geckoides, regression of the number of fourth toe lamellae on latitude.

neighboring localities at the same approximate altitude. The same was done for the samples with more than one locality.

Both the number of tubercles and of lamel-

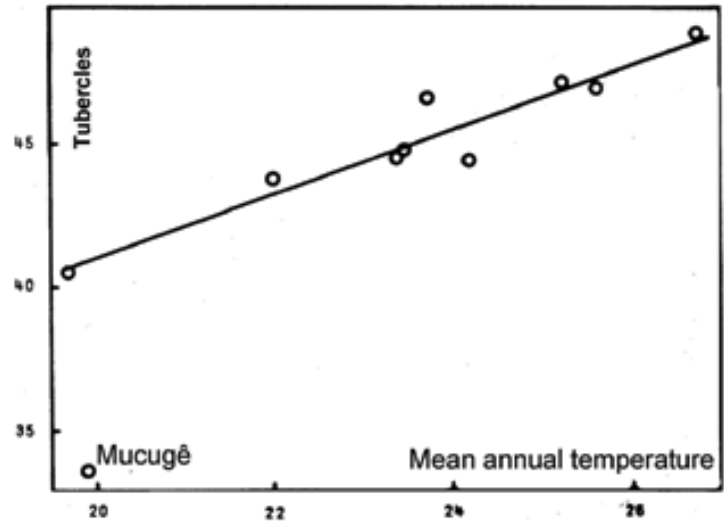

Graph 4 - Gymnodactylus geckoides, regression of the number of tubercles in a paramedian. row on mean annual temperature.

lae are significantly related to rainfall, although the quality of the regressions is not very high (Tables XI and XII). It should be noted that, in the geographical space sampled, temperature and rainfall are not 
correlated (Table XII).

Comment. These ecological correlations have interesting evolutiuonary implications. Even the strong discrepancies (no doubt caused by environmental factors not considered here) in such wellordered processes acquire conceptual relevance. The ensemble of data, significant regressions and exceptions, strongly indicates that G. geckoides is sensitive to environmental conditions and responds conspicuously, and probably rapidly, to them. Any study of speciation must keep in mind the possibility of parapatric differentiation.

\section{Geographical Pattern}

The next step I took in the study of geographical differentiation of G. geckoides in the caatingas was to visualize the relationships among samples as revealed by Tukey's test. This can conveniently be done by portraying graphically the differences between geographically adjacent samples on "skeleton maps", in which coordinates are plotted on a cartesian graph, simulating the spatial relationships without the encumbrance and considerable labor of actual maps.

The three meristic characters studied showed geographical heterogeneity in the analysis of variance, but the application of Tukey's test did not reveal any pattern in the case of ventrals. This is not infrequently the case: the powers of discrimination of the two tests differ. Thus I have considered only tubercles in a paramedian row and fourth toe lamellae. Both characters present relatively simple patterns.

Tubercles (Tables V and VI, Graph 5). The northern samples, south to Caatinga do Moura show a mild mosaic, without any definite pattern. In the south, Mucugê has significantly low values, and Morro do Chapéu is intermediate both geographically and in the number of tubercles.

Lamellae (Tables VII-VIII, Graph 6). The geographical distribution of the number of fourth toe lamellae follows a pattern similar to that of tubercles in a paramedian row. The northern samples are fairly homogeneous. Mucugê has very high counts, and

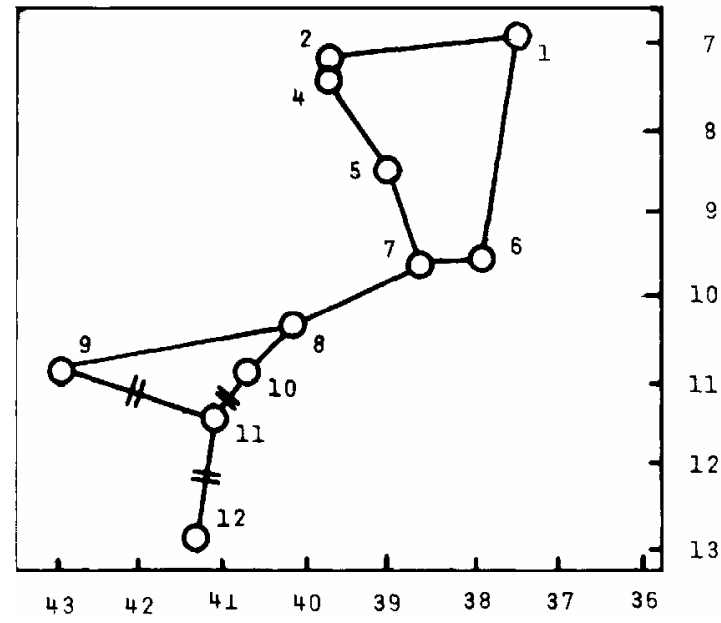

Graph 5 - Gymnodactylus geckoides, tubercles in a paramedian row, Tukey's test. Cross-hatching indicates that the samples differ significantly. 1. Paraíba, 2. Santana do Carirí, 4. Exu, 5. Sertão de Pernambuco, 6. Raso da Catarina, 7. Senhor do Bonfim, 8. Xingó, 9. S. Francisco, 10. Caatinga do Moura, 11. Morro do Chapéu, 12. Mucugê.

the geographically intermediate samples are roughly statistically intermediate.

Superciliary flap. In the geckos there is a superciliary fold of skin, that was sometimes referred to as an eyelid. Underwood (1954: 472) showed that it was merely what he called "a prominent extrabrillar fringe', which I (Vanzolini 1978) prefer to call, descriptively, a superciliary flap.

In geckoides the fold is conspicuous, paved with granules; frequently there are some flat, enlarged granules at the anterior end. In Mucugê these flat granules are much better developed than in any other sample, especifically than in Morro do Chapéu. This is a small, but, in geckos, a suggestive difference.

Color pattern. It has been seen that in the genus Gymnodactylus color pattern plays a significant role; there are marked differences among geckoides, darwinii, amarali and guttulatus. In the caatingas, the dorsal color pattern of G. geckoides is variable, from a fuliginous brown poorly patterned with blackish markings, to passably aligned rows of light markings, varying in distinctness, frequently edged 


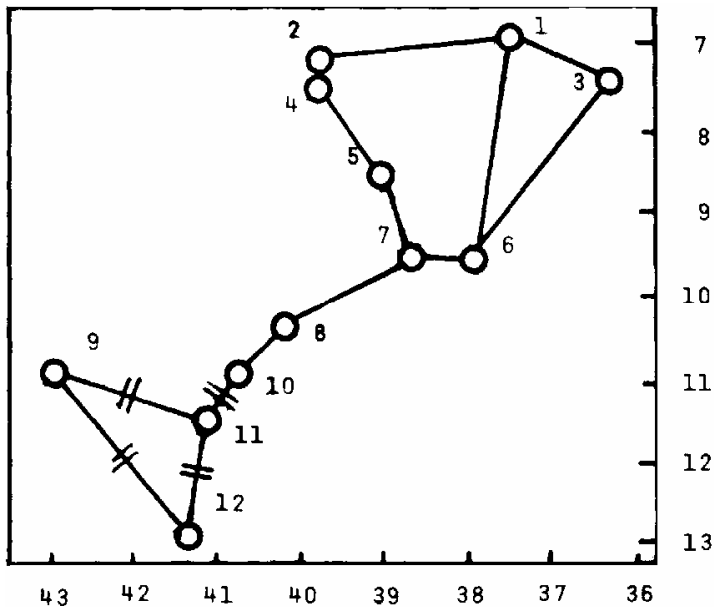

Graph 6-Gymnodactylus geckoides, fourth toe lamellae, Tukey's test. Cross-hatching indicates that the samples differ significantly. 1. Paraíba, 2. Santana do Carirí, 3. Cabaceiras, 4. Exu, 5. Sertão de Pernambuco, 6. Raso da Catarina, 7. Senhor do Bonfim, 8. Xingó, 9. São Francisco, 10. Caatinga do Moura, 11. Morro do Chapéu, 12. Mucugê.

with black, completely (ocelli) or not. In Morro do Chapéu the whole gamut is seen. I found, with the exception to be next noted, much variation, but no geographical regularities in this character. In $\mathrm{Mu}-$ cugê, and only in Mucugê, a different pattern was found.

The dorsum shows (Plate 1A) a pattern of medium-brown ground color with 6-9 relatively bold blackish crossbars, either complete across or in alternating halves. The dorsal aspect of the limbs is also marked with bars, transverse or oblique, sometimes reaching the ventral surface on the sides; the digits are spotted. The head at its most patterned shows a dark stripe from the nostril to the eye, light- bordered above; on the snout, a dark chevron; on the top of the head and nape coarse irregular black vermiculations. The upper lip may be immaculate or lightly spotted. The tail has transverse black rings 3-4 granules long, separated by light brown interspaces 5-6 granules long. The ventral parts are cream-colored, unspotted. All the dark markings may show different degrees of intensity.

Conclusion. It seems clear that the samples at hand can be divided in three classes: (i) Mucugê, with distinctive scale counts and color pattern: (ii) the rather uniform samples from Caatinga do Moura north; (iii) Morro do Chapéu, partly intermediate. Such a pattern can be interpreted in two ways: the Mucugê population has differentiated in a refuge, or we have a case of a threshold parapatric model, such as proposed by Sewall Wright (1967) and very clearly discussed by Pielou (1979: 85 seq.). I prefer the refuge model, as there is parallel differentiation of two uncorrelated characters, tubercles and lamellae, and also, of decisive relevance, because the area of differentiation is Mucugê.

\section{DISCUSSION}

That Mucugê appears as a site of geographic differentiation of a caatinga species of animal should not come as a surprise. In spite of not being in an extensively collected area, it is the home of one endemic genus of amphibians, Rupirana Heyer, 1999, of one endemic species of lizard, Tropidurus тисиjensis Rodrigues, 1987, and of one endemic species of hummingbird, Augastes lumachellus (Lesson 1838) (apud Sick 1984: 381).

As said, G. geckoides is essentially a denizen of the morphoclimatic domain of the caatingas. The concept of morphoclimatic domains was applied by Ab'Sáber first to Brasil (1967) and later (1977b) extended to the whole of South America. A morphoclimatic domain is (Ab'Sáber 2003: 11) a large spatial ensemble (hundreds of thousands to millions of square kilometers) containing a coherent arrangement of relief, soils, vegetation, hydrology and climate. Each domain has a core area, usually polygonal, where physiographic and biological features are integrated in a homogeneous complex. The core areas of adjacent domains are separated by narrow, elongate belts, showing distinctive local combinations of vegetation, soils and relief; they are not, and this is very important, areas of gradual transition.

The domain in question was formally called by Ab'Sáber (1967) the "domain of semi-arid interplateau depressions of northeastern Brasil'". However, as stated by Tricart (1958: 2), vegetation is the best synthetic expression of climatic features, and the domain is more widely known, after the charac- 
teristic vegetation, as the domain of the caatingas. In fact, there are authors (e.g. Velloso et al. 2002) who prefer the term "biome", which stresses the vegetation, in spite of the broader scope and obvious advantages, theoretical and practical, of Ab'Sáber's concept.

In his latest paper, Ab'Sáber (2003: 14) thus characterized the domain:

1. It is a semi-arid region, latitudinally subequatorial to tropical, measuring 700,000850,000 square kilometers (my own estimate is closer to $900,000 \mathrm{sq} \mathrm{km}$ ).

2. Geomorphologically, it is mostly constituted of inter-plateau depressions, reduced by erosion practically to plains studded with low hills.

3. There is very little decomposition of bedrock, the regolith being usually 0-3 m thick; there are widespread outcrops of rock, commonly constituting stone floors.

4. The climate is dry (yearly rainfall 350$600 \mathrm{~mm}$ ), hot (which accentuates the dryness), and extremely irregular in space and time; there are frequent years of severe drought as well as (of course much rarer) years of extensive floods.

5. The drainage is intermittent, and, very important, outflowing ( non-centripetal), which explains the absence of evaporite-rich, desertic features, such as playas and alkali flats.

Mucugê is on the Serra de Sincorá, which is part of the Chapada Diamantina, itself the northern half of the great range known as Serra do Espinhaço ("the Backbone"). This is a roughly N-S trending mountain range of Proterozoic age, much folded and eroded, reduced to a series of aligned tabuliform surfaces $800-1000 \mathrm{~m}$ high. There are two main nuclei, a southern one in the State of Minas Gerais, surrounded by cerrados, of which a segment, the Serra do Cipó, has been zoologically fairly well explored, and a northern one in Bahia, surrounded by caatingas, known as the Chapada Diamantina or, in geological and geomorphological parlance, the "Pro- terozoic Plateaux" (Map 2). There is great ecological difference between this area and the caatingas.

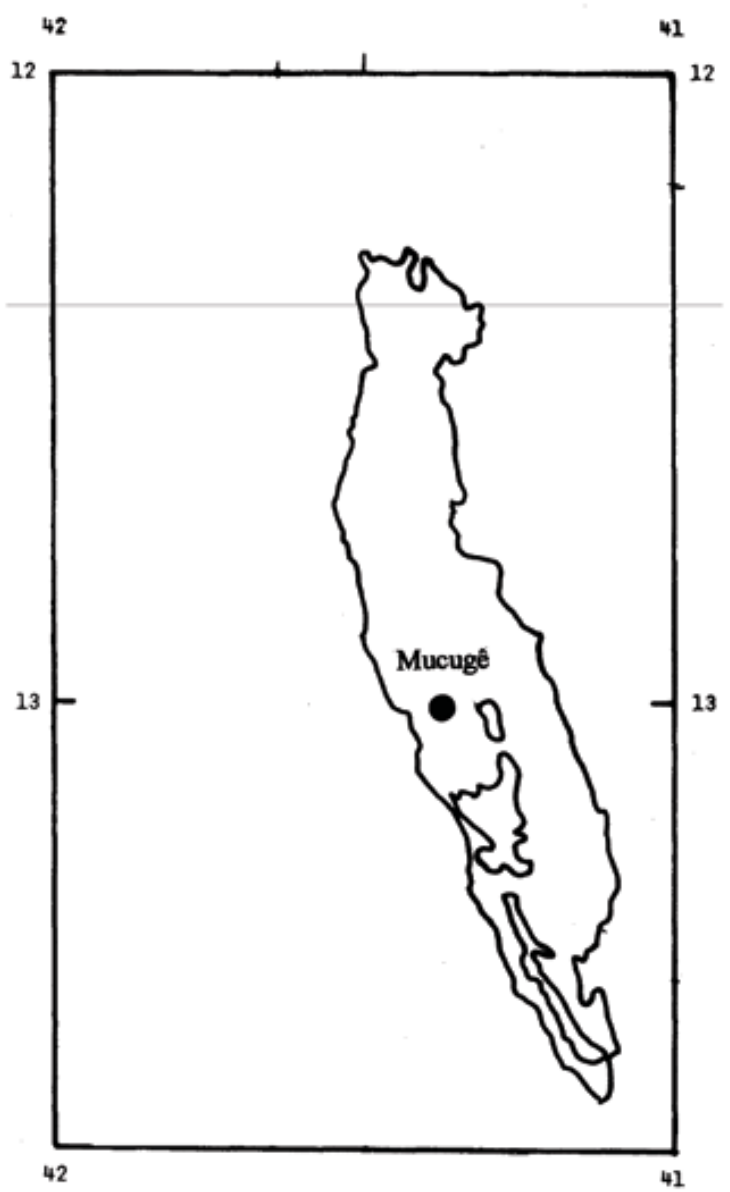

Map 2 - Mucugê in the context of the "Proterozoic Plateaux", (from Projeto Radambrasil 1981, vol. 24).

The vegetation determined by the harsh conditions of the semi-arid domain obviously shows adaptations against loss of water, morphological (wax, thorns) and physiological (closure of stomata, dryseason deciduousness). Cacti and other succulents are conspicuous. During the dry season all leaves fall; the vegetation acquires an ashy tinge that is at the root of its indigenous (Tupi) name: caa tinga $=$ white woods.

Of course the caatingas are also very specialized floristically; good summaries are found in Andrade-Lima (1981), Brazão and Araujo (1981) and Gonçalves and Orlandi (1983). The last two papers, in the discipline of Projeto Radambrasil, adopt 
the so-called "Sistema Fitogeográfico Brasileiro" (Veloso et al. 1975), which has by no means won general acceptance, but their field surveys and species lists are thorough and workmanlike. Gonçalves and Orlandi (1983) classify the vegetation of the general Mucugê area as "montane ecological refuge", refuge to them meaning "all and any vegetation floristically different from the general context of the regional flora" - for all purposes an enclave, a meaningful concept in the present context.

Velloso et al. (2002), in their application to the "caatinga biome" of Bailey's (1998) concept of ecoregions, consider the "Chapada Diamantina Complex" as a facies of the caatingas, and ascribe to it a vegetational mosaic, including caatinga, very diversified, on the lower levels (below 1,000 m), cerrados, campos rupestres and forest, from very dry to very humid. Recent opinion (Harley and Simmons 1986, Giulietti and Pirani 1988, Harley 1995, Seabra 1998) emphasizes the presence of campos rupestres on the upper surfaces of the Espinhaço. (These campos are a formation for which no suitable English name has been proposed, so I follow Giulietti and Pirani 1988, Harley 1995 and Heyer 1999, in using the Brazilian term, without quotation marks.)

The campos rupestres have been described in detail by Harley and Simmons (1986) and by Giulietti and Pirani (1988). Their phytogeographic relationships are complex and not yet fully understood, but there is no doubt about their ecological and taxonomic individuality.

Besides campos rupestres, there are in the Chapada Diamantina extensive areas of cerrados (" campos gerais", etc; Brazão and Araujo 1981, Harley and Simmons 1986, Harley 1995, Seabra 1998, map following page 194; Grillo 2000). Harley and Simmons (1986: 11) say: "the campos gerais... cover extensive parts of the Chapada on flat, sandy or latosolic plains such as are found to the south and east...'”

It is evident that the upper reaches of the Chapada Diamantina are not uniformly under caatingas.

My sample comprises seven specimens catalogued as from "Mucugê, Bahia"; five of them have no further particulars, but two have the mention
" $1020 \mathrm{~m}$ ". This would place them in the campos rupestres, which predominate above $900 \mathrm{~m}$ (Harley and Simmons 1986: 7, Giulietti and Pirani 1988: 40). This is an interesting point, but not really essential to the argument, in view of the variety of non-caatinga environments available.

In Graph 7 are compared the temperature and rainfall data of Mucugê, of Canudos, in the stark caatinga of northern Bahia, and of Barra da Estiva, in cerrado some $70 \mathrm{~km}$ almost due-south of $\mathrm{Mu}$ cugê. It is clear that Mucugê conforms to a typical cerrado paradigm, a moderate climate with marked seasonality and reasonable rainfall. "The Chapada owes its rich flora to the humid mesothermic climate of mild, wet summers with rain clouds driven westwards from the Atlantic watering its higher and easterly slopes.' (Harley and Simmons, 1986: 3).

In addition to these ecological characteristics of the Chapada Diamantina, there is plentiful evidence of paleoclimatic events that would make it an isolated refuge in the not-distant past. This evidence comes from the two usual main sources, geomorphological and paleopalynological.

The geomorphological contribution consists of the observation of features of the superficial structure of the landscape attributable to paleoclimatic causes (Ab'Sáber 1955, 1956, 1969, 1977a, Dresch 1957, Tricart 1958). These observations, made on a very broad geographical scale, at least opened the field for conjecture. There is, however, one pollen profile (Oliveira et al. 1999), from a critical locality in the caatingas, the fossil dunes of the middle Rio São Francisco, at 1024, 4313, fully relevant in the present context. In it are identified five pollen zones, with the following C-14 ages and climatic characteristics:

- SA 1, 10990-10540 yr BP, very humid (forest, no cerrado).

- SA 2, 10540-6790 yr BP, progressively warmer and drier, with cerrado and caatinga, increasingly drier from 8910 to $6790 \mathrm{yr}$ BP.

- SA 3, 6790 - ca. 6230 yr BP, no pollen found, possibly semi-arid.

- SA 4, ca. 6230 - ca. 4535 yr BP, relatively 


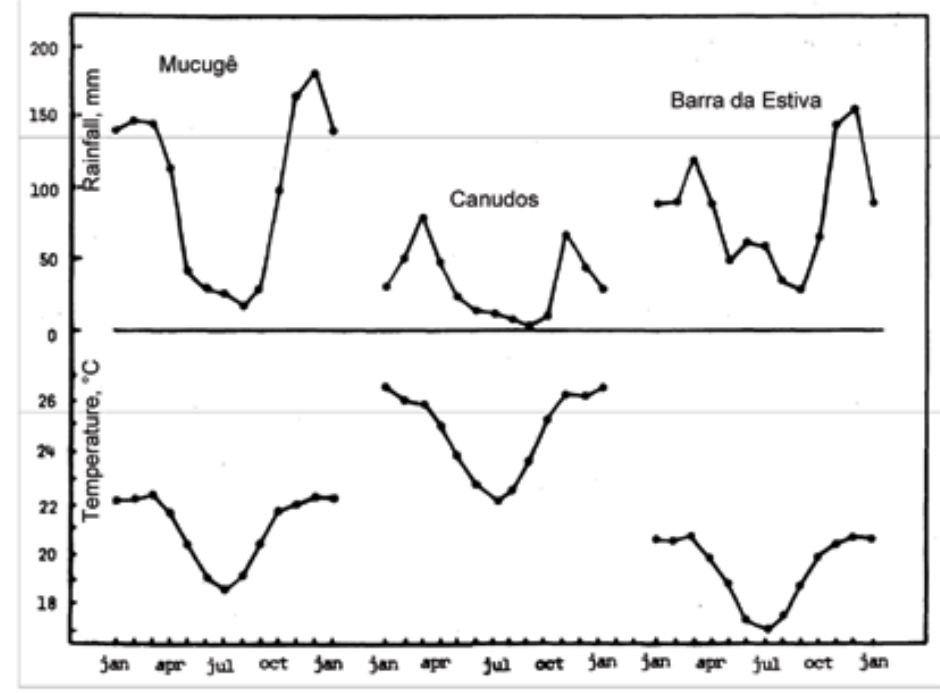

Graph 7 - Climate diagrams for Mucugê and for one caatinga (Canudos) and one cerrado (Barra da Estiva) localities.

moist, evolving into a mixed vegetation, caatinga and cerrado, with gallery forest.

- SA 5, ca. 4535 yr BP to present, drier, leading to the present conditions of semi-aridity.

These fast climatic changes are thought by the authors (Oliveira et al. 1999) to be compatible with current ideas about the climatic evolution of Brazil in the Holocene (e.g. Prado and Gibbs 1993, Ledru et al. 1994, 1996, 1998). There is indeed in the literature a sufficiency of humid episodes to sustain the idea of a Gymnodactylus population insulated in the Chapada Diamantina, in fairly recent times (possibly as little as $11,000 \mathrm{yr}$ B.P.) by a mesic matrix. In fact, Harley and Simmons (1986: 5) say about the isolated "brejo" forest isolates on the Chapada: "they would seem to be relict communities from a period when forest covered a much greater area of NE Brazil...'.

In such isolation and changed climate, a labile, genetically malleable lizard such as Gymnodactylus geckoides would find every encouragement to differentiate. This is the type of model previously proposed by myself (Vanzolini 1997) to account for speciation in cerrado amphisbaenians.
Otherwise, morphologcal homogeneity over such a large territory (ca 400,000 sq km) agrees well with the recency of distributional phenomena in the caatingas.

\section{CONCLUSION}

I think that, in sketching a first outline of the geographical differentiation of G. geckoides, a caatinga lizard, this study has accomplished its purpose. The matter remains of the taxonomic rank to be attributed to the Mucugê population, which may be a subspecies or a full species. I believe that the data available are not sufficient for a rational decision - in fact I think that such a decision is not at present necessary. To me the important point is that differentiation occurred, driven by paleoclimatic causes, in a modern, Holocene frame. The pattern stands, to be deepened and extended by better data (more detailed collecting) and improved (molecular) methods. It should also be profitable to investigate, in this frame of mind, other areas of the Espinhaço, such as the region of Guinda, in Minas Gerais, the type locality of G. guttulatus Vanzolini, 1982. 


\section{GAZETTEER}

Coordinates simplified, approximate elevations between parentheses.

Arajara, CE. 0721, 3924 (ca. 750 m)

Baixa Verde, RN. 0532, 3548 (144 m); now João Câmara

Barra, BA. 1105, 4309 (410 m)

Barra da Estiva, BA. 1338, 4120 (1053 m)

Bom Jesus da Lapa, BA. 1315, 4325 (429 m)

Cabaceiras, PB. 0730, 3617 (390 m)

Cana Brava, TO. 1247, 4653 (ca. $600 \mathrm{~m}$ )

Canudos, BA. 0953, 3913 (350 m)

Carnaubeira, PE. 0818,3845 (450 m)

Caatinga do Moura, BA. 1058, 4045 (ca. $700 \mathrm{~m}$ )

Ceará Mirim, RN. 0538, 3524 (18 m)

Custódia, PE. 0807, 3739 (540 m)

Encruzilhada, PE. 0841, 4007 (ca. 390 m)

Engenheiro Dodt, PI. 0848, 4556 (280 m)

Extremoz, RN. 0542, 3519 (ca. $40 \mathrm{~m}$ )

Exu, PE. 0731, 3943 (510 m)

Floresta do Navio, PE. 0835, 3835 (320 m)

João Câmara, RN. 0532, 3548 (144 m); formerly Baixa Verde

km 353 Patos - Malta, PB. 0655, 3732 (ca. 330 m)

Malta, PB. 0654, 3731 (340 m)

Morro do Chapéu, BA. 1133, 4109 (1023 m)

Mucugê, BA. 1300, 4123 (870 m)

Natal, RN. 0548, 3512 (s.l.)

Patos, PB. 0702, 3716 (315 m)

Paulo Afonso, AL/BA. 0924, 3813 (243 m)

Piancó, PB. 0710, 3756 (250 m)

Piranhas Nova, AL. 0937, 3753 (110 m) (a neighborhood in Xingó)

Queimadas, BA. 1037, 4236 (275 m)

Raso da Catarina, BA. 0940, 3840 (ca. $400 \mathrm{~m}$ )

Salvador, BA. 1300, 3830 (s.l.)

Santa Luzia, PB. 0652, 3656 (290 m)

Santana do Carirí, CE. 0711, 3944 (480 m)

São José de Espinharas, PB. 0650, 3719 (185 m)

São Sebastião, Ilha de, SP. 2349, 4520 (s.1.)

Senhor do Bonfim, BA. 1027, 4011 (540 m); formerly Villa Nova

Vacaria, BA. 1039, 4237 (ca. $420 \mathrm{~m}$ )

Villa Nova, BA. 1027, 4011 (540 m); now Senhor do Bonfim

Xingó, AL. 0937, 3753 (65 m)

Xiquexique, BA. 1050, 4243 (580 m) 


\section{APPENDIX - RAW DATA}

Abbreviations: MZUSP, number in the collection. Length: body + tail. Tubercles trv, counted transversely at midbody; lgt, in a paramedian row. Ventr: ventral scales counted transversely at midbody. Lam: fourth toe lamellae.

\begin{tabular}{|c|c|c|c|c|c|c|c|}
\hline \multirow[t]{2}{*}{ MZUSP } & \multirow[t]{2}{*}{ Locality } & \multirow[t]{2}{*}{ Sex } & \multirow[t]{2}{*}{ Lenght } & \multicolumn{2}{|c|}{ Tubercles } & \multirow[t]{2}{*}{ Ventr. } & \multirow[t]{2}{*}{ Lam } \\
\hline & & & & $\operatorname{trv}$ & $\operatorname{lgt}$ & & \\
\hline \multicolumn{2}{|l|}{ Ce a rá } & & & & & & \\
\hline 54015 & Santana do Cariri & $\mathrm{j}$ & $35+x$ & 12 & 53 & 21 & 14 \\
\hline 54018 & " & $\sigma^{x}$ & $43+x$ & 12 & - & 22 & 15 \\
\hline 54020 & $"$ & $\sigma^{\pi}$ & $46+x$ & 12 & - & - & 16 \\
\hline 54023 & $"$ & $\sigma^{\pi}$ & $45+x$ & 12 & 54 & 21 & 16 \\
\hline 54024 & $"$ & $\mathrm{j}$ & $21+x$ & 12 & - & - & 15 \\
\hline \multicolumn{2}{|c|}{ Paraíb a } & & & & & & \\
\hline 59110 & Cabaceiras & $q$ & $40+x$ & 12 & - & 21 & 14 \\
\hline 59111 & " & $\mathrm{j}$ & $21+x$ & - & - & - & 14 \\
\hline 59112 & $"$ & $\mathrm{j}$ & $21+x$ & 12 & 47 & 20 & 14 \\
\hline 59113 & $"$ & q & $42+x$ & 12 & - & 21 & 14 \\
\hline 59114 & $"$ & $\mathrm{j}$ & $8+x$ & 12 & 47 & 19 & 16 \\
\hline 59115 & $"$ & q & $39+44$ & 12 & 50 & - & 15 \\
\hline 56958 & km 353 Patos-Malta & q & $39+x$ & 12 & 47 & 21 & 16 \\
\hline 5585 & Piancó & $\mathrm{j}$ & $23+30$ & 12 & - & 21 & 14 \\
\hline 5587 & $"$ & $\mathrm{j}$ & $34+41$ & 12 & 48 & 19 & 14 \\
\hline 5588 & " & $\sigma^{\pi}$ & $35+45$ & 12 & 46 & 20 & 16 \\
\hline 4034 & Santa Luzia & $\mathrm{j}$ & $32+x$ & 12 & 49 & - & 15 \\
\hline 4035 & " & $\mathrm{j}$ & $37+x$ & 12 & - & - & 14 \\
\hline 44528 & S. José de Espinharas & $\mathrm{j}$ & $38+45$ & - & - & - & 15 \\
\hline 44529 & " & $\mathrm{j}$ & $38+x$ & 12 & 47 & 21 & 14 \\
\hline 44531 & $"$ & $\mathrm{j}$ & $37+x$ & 12 & 48 & - & 16 \\
\hline \multicolumn{2}{|c|}{ Pernambuco } & & & & & & \\
\hline 506 & Paulo Afonso & $\mathrm{j}$ & $33+37$ & 12 & 45 & 22 & 17 \\
\hline 22263 & Carnaubeira & $\sigma^{7}$ & $42+49$ & 12 & - & 23 & 15 \\
\hline 22264 & " & - & $42+x$ & 12 & - & 20 & 16 \\
\hline 22265 & $"$ & q & $52+x$ & 12 & 47 & 21 & 15 \\
\hline 23119 & Floresta do Navio & $\mathrm{j}$ & $24+x$ & 12 & 45 & 20 & 16 \\
\hline 23120 & " & $\mathrm{j}$ & $37+x$ & 12 & 44 & 22 & - \\
\hline 23121 & $"$ & $\mathrm{j}$ & $34+x$ & 12 & 48 & 20 & 18 \\
\hline 23122 & " & $\sigma^{\pi}$ & $37+44$ & 12 & 43 & 21 & 15 \\
\hline 57780 & Encruzilhada & $\mathrm{j}$ & $32+x$ & 12 & 50 & 20 & 17 \\
\hline 57781 & " & q & $42+52$ & 12 & 46 & 21 & 16 \\
\hline 57782 & $"$ & q & $41+x$ & 12 & 48 & 20 & 15 \\
\hline 57783 & $"$ & $\mathrm{j}$ & $38+52$ & 12 & 52 & 23 & 15 \\
\hline
\end{tabular}


APPENDIX - RAW DATA ( continuation )

\begin{tabular}{|c|c|c|c|c|c|c|c|}
\hline \multirow[t]{2}{*}{ MZUSP } & \multirow[t]{2}{*}{ Locality } & \multirow[t]{2}{*}{ Sex } & \multirow[t]{2}{*}{ Lenght } & \multicolumn{2}{|c|}{ Tubercles } & \multirow[t]{2}{*}{ Ventr. } & \multirow[t]{2}{*}{ Lam. } \\
\hline & & & & $\operatorname{trv}$ & lgt & & \\
\hline \multicolumn{2}{|c|}{ Pernambuco } & & & & & & \\
\hline 45132 & Exu & $\mathrm{j}$ & $25+x$ & 12 & 44 & 21 & 17 \\
\hline 47925 & " & q & $38+52$ & 12 & 43 & 20 & - \\
\hline 47927 & $"$ & q & $41+x$ & 12 & - & 20 & 15 \\
\hline 47928 & " & $\sigma^{7}$ & $39+54$ & 12 & - & 23 & 16 \\
\hline 47929 & " & $\sigma^{x}$ & $40+55$ & 12 & - & 24 & 18 \\
\hline 47930 & " & q & $41+53$ & 12 & 42 & 21 & 16 \\
\hline 47931 & " & 우 & $41+x$ & 12 & 46 & 22 & 15 \\
\hline 47932 & " & 우 & $42+x$ & 12 & 45 & 23 & 16 \\
\hline 47933 & " & $\sigma^{x}$ & $39+55$ & 12 & 47 & 22 & 19 \\
\hline 47936 & " & $\mathrm{j}$ & $20+24$ & 12 & - & - & 15 \\
\hline 47937 & " & q & $42+x$ & 12 & 41 & 21 & 15 \\
\hline 47938 & " & $\sigma^{x}$ & $41+59$ & 12 & - & 22 & 15 \\
\hline 47939 & " & q & $29+38$ & - & - & 20 & 14 \\
\hline 47940 & " & q & $45+x$ & 12 & 50 & 21 & 13 \\
\hline 47941 & $"$ & $\mathrm{j}$ & $21+25$ & 12 & 41 & - & 14 \\
\hline 47942 & " & q & $40+x$ & 12 & 46 & 18 & 15 \\
\hline 47943 & " & $\sigma^{7}$ & $37+x$ & 12 & 47 & 20 & 15 \\
\hline 47944 & " & ㅇ & $35+x$ & 12 & - & 20 & 15 \\
\hline 47945 & " & 우 & $29+37$ & - & - & - & 14 \\
\hline 47946 & " & $\sigma^{7}$ & $26+35$ & 12 & 41 & 21 & 15 \\
\hline 47947 & $"$ & $\sigma^{7}$ & $41+x$ & 12 & - & 20 & - \\
\hline 47948 & $"$ & $\sigma^{x}$ & $40+x$ & 12 & 43 & 21 & 15 \\
\hline 47949 & $"$ & q & $43+x$ & - & - & - & 15 \\
\hline 47950 & " & $\sigma^{x}$ & $43+x$ & - & - & - & 15 \\
\hline 49751 & " & ㅇ & $44+x$ & 12 & 49 & 18 & 15 \\
\hline 47952 & " & q & $37+45$ & 12 & 45 & 20 & 16 \\
\hline 47953 & $"$ & $\sigma^{\pi}$ & $45+x$ & 12 & - & 20 & - \\
\hline 47954 & " & ㅇ & $36+50$ & 12 & 39 & 20 & 14 \\
\hline 47955 & $"$ & $\sigma^{7}$ & $35+46$ & 12 & 44 & 20 & 14 \\
\hline 47956 & " & $\mathrm{j}$ & $40+55$ & 12 & 43 & 19 & 15 \\
\hline 47957 & " & $\mathrm{j}$ & $20+23$ & 12 & - & 20 & - \\
\hline 47958 & $"$ & q & $43+x$ & 12 & 45 & 20 & 16 \\
\hline 47959 & " & $\sigma^{x}$ & $37+x$ & 12 & 41 & 21 & 15 \\
\hline 47960 & $"$ & q & $40+x$ & 12 & - & 21 & 16 \\
\hline 47961 & " & $\mathrm{j}$ & $35+50$ & 12 & - & 21 & - \\
\hline
\end{tabular}


APPENDIX - RAW DATA ( continuation )

\begin{tabular}{|c|c|c|c|c|c|c|c|}
\hline \multirow[t]{2}{*}{ MZUSP } & \multirow[t]{2}{*}{ Locality } & \multirow[t]{2}{*}{ Sex } & \multirow[t]{2}{*}{ Lenght } & \multicolumn{2}{|c|}{ Tubercles } & \multirow[t]{2}{*}{ Ventr. } & \multirow[t]{2}{*}{ Lam. } \\
\hline & & & & trv & $\operatorname{lgt}$ & & \\
\hline \multicolumn{2}{|c|}{ Pernambuco } & & & & & & \\
\hline 47962 & Exu & 우 & $38+49$ & 12 & 42 & 21 & 15 \\
\hline 47963 & " & $\sigma^{\pi}$ & $36+40$ & 12 & 46 & 21 & 16 \\
\hline 47964 & $"$ & $\mathrm{j}$ & $42+x$ & - & - & - & 15 \\
\hline 47965 & $"$ & $\mathrm{j}$ & $40+x$ & 12 & 44 & 22 & 15 \\
\hline 47967 & $"$ & q & $38+x$ & 12 & 44 & 20 & 16 \\
\hline 47968 & $"$ & $\mathrm{j}$ & $36+44$ & 12 & - & 21 & 15 \\
\hline 47969 & $"$ & $\mathrm{j}$ & $41+50$ & 12 & 48 & 21 & 15 \\
\hline 47970 & " & $\sigma^{\top}$ & $38+53$ & 12 & - & 21 & 15 \\
\hline 47971 & $"$ & $\mathrm{~J}$ & $38+X$ & 12 & - & 20 & 16 \\
\hline 47972 & $"$ & ㅇ & $42+46$ & 12 & 45 & 21 & 15 \\
\hline 47973 & $"$ & $\sigma^{7}$ & $39+x$ & 12 & 41 & 21 & 14 \\
\hline 47974 & $"$ & $\sigma^{7}$ & $41+x$ & 12 & 44 & 21 & 16 \\
\hline 47975 & " & $\sigma^{x}$ & $19+x$ & 12 & 45 & - & - \\
\hline 47976 & $"$ & $0^{x}$ & $26+x$ & 12 & 49 & 22 & 15 \\
\hline 47977 & " & q & $41+51$ & 12 & 45 & 22 & 16 \\
\hline 47981 & " & ㅇ & $40+x$ & 12 & 46 & 24 & 17 \\
\hline 47982 & " & $\sigma^{\top}$ & $30+36$ & 12 & 48 & 22 & 17 \\
\hline 47983 & " & $\sigma^{7}$ & $26+x$ & 12 & 45 & 21 & 18 \\
\hline 47984 & " & O & $40+46$ & 12 & 45 & 22 & 18 \\
\hline 47985 & $"$ & 우 & $40+x$ & 12 & - & 20 & 15 \\
\hline 47986 & $"$ & $\sigma^{7}$ & $31+36$ & 12 & 44 & 20 & 18 \\
\hline 47987 & " & ㅇ & $42+x$ & 12 & 46 & 20 & 17 \\
\hline 47988 & $"$ & $\sigma^{\top}$ & $44+x$ & - & - & 21 & 19 \\
\hline 47990 & $"$ & $\sigma^{7}$ & $41+x$ & - & - & - & 15 \\
\hline 47991 & $"$ & Q & $43+x$ & 12 & - & - & 17 \\
\hline 47992 & $"$ & $\sigma^{7}$ & $40+x$ & 12 & - & 21 & 17 \\
\hline 47993 & $"$ & $\sigma^{7}$ & $40+53$ & 12 & - & - & 16 \\
\hline 47994 & $"$ & $0^{x}$ & $42+x$ & 12 & 48 & 22 & 15 \\
\hline 47995 & " & ㅇ & $43+x$ & - & - & - & 18 \\
\hline 47997 & $"$ & 우 & $42+x$ & 12 & 44 & - & 16 \\
\hline 47999 & $"$ & 우 & $37+x$ & 12 & 44 & 20 & 16 \\
\hline 48000 & " & ㅇ & $43+x$ & 12 & - & 21 & 14 \\
\hline 48002 & $"$ & $\sigma^{7}$ & $42+52$ & 12 & 44 & 22 & - \\
\hline 48005 & $"$ & 우 & $38+45$ & 12 & 41 & 19 & 16 \\
\hline 48007 & " & 우 & $42+52$ & 12 & - & 20 & 15 \\
\hline 48008 & $"$ & 우 & $40+x$ & 12 & 43 & 22 & 14 \\
\hline
\end{tabular}


APPENDIX - RAW DATA ( continuation )

\begin{tabular}{|c|c|c|c|c|c|c|c|}
\hline \multirow{2}{*}{ MZUSP } & \multirow{2}{*}{ Locality } & \multirow{2}{*}{ Sex } & \multirow{2}{*}{ Lenght } & \multicolumn{2}{|c|}{ Tubercles } & \multirow[t]{2}{*}{ Ventr. } & \multirow[t]{2}{*}{ Lam. } \\
\hline & & & & $\operatorname{trv}$ & $\operatorname{lgt}$ & & \\
\hline \multicolumn{2}{|c|}{ Pernambuco } & & & & & & \\
\hline 48009 & Exu & 우 & $38+41$ & 12 & - & 20 & 14 \\
\hline 48010 & " & 우 & $27+x$ & 12 & 41 & 20 & 14 \\
\hline 48011 & $"$ & q & $39+x$ & - & 43 & - & 16 \\
\hline 48012 & $"$ & $\sigma^{7}$ & $42+x$ & 14 & 45 & 21 & 15 \\
\hline 48013 & $"$ & q & $41+x$ & 12 & - & - & 16 \\
\hline 48014 & $"$ & $\mathrm{j}$ & $25+x$ & 12 & 39 & - & 15 \\
\hline 48015 & $"$ & 우 & $40+46$ & 12 & 43 & 20 & 16 \\
\hline 48016 & $"$ & $\sigma^{\pi}$ & $37+x$ & 12 & 42 & 21 & 15 \\
\hline 48017 & $"$ & $\sigma^{7}$ & $35+x$ & 12 & 47 & 20 & 16 \\
\hline 48018 & $"$ & 우 & $44+x$ & 12 & 47 & 22 & 16 \\
\hline 48021 & $"$ & $\sigma^{7}$ & $37+x$ & 12 & 43 & 20 & 14 \\
\hline 48119 & $"$ & $\sigma^{7}$ & $40+x$ & 12 & 47 & 24 & 17 \\
\hline 48120 & $"$ & $\mathrm{j}$ & $19+x$ & 12 & 44 & 21 & - \\
\hline 48121 & $"$ & 우 & $36+41$ & 12 & 46 & 23 & 18 \\
\hline 49683 & $"$ & 우 & $42+x$ & 12 & 38 & 20 & 16 \\
\hline 49684 & $"$ & 우 & $42+x$ & 12 & 38 & 20 & 16 \\
\hline 49685 & $"$ & $\sigma^{7}$ & $39+x$ & 12 & - & 19 & - \\
\hline 49686 & $"$ & $\sigma^{x}$ & $40+x$ & 12 & - & 21 & 14 \\
\hline 49687 & $"$ & $\sigma^{x}$ & $37+x$ & 12 & 49 & 21 & 15 \\
\hline 49688 & $"$ & q & $40+49$ & 12 & 47 & 22 & 15 \\
\hline 49690 & $"$ & $\sigma^{x}$ & $33+40$ & - & - & - & 15 \\
\hline 49692 & $"$ & $0^{x}$ & $40+x$ & - & - & 20 & 14 \\
\hline 49699 & $"$ & ㅇ & $42+x$ & 12 & 51 & - & 15 \\
\hline 49703 & $"$ & $0^{x}$ & $40+x$ & 12 & - & - & 14 \\
\hline 49708 & $"$ & q & $41+x$ & - & - & - & 15 \\
\hline 49709 & $"$ & 우 & $37+41$ & 12 & 45 & 21 & 15 \\
\hline 49714 & $"$ & 우 & $41+x$ & 12 & - & 21 & 14 \\
\hline 49718 & $"$ & O & $42+x$ & 12 & - & 20 & 17 \\
\hline 49741 & $"$ & $\sigma^{7}$ & $41+x$ & 12 & 44 & 20 & 16 \\
\hline 49746 & $"$ & q & $27+32$ & 12 & - & - & 15 \\
\hline 49750 & " & 우 & $42+x$ & 10 & 41 & 20 & 15 \\
\hline 49755 & $"$ & 우 & $40+x$ & 12 & 44 & 22 & 15 \\
\hline 49757 & $"$ & $\sigma^{x}$ & $39+48$ & 12 & 45 & 19 & 16 \\
\hline 49758 & $"$ & ㅇ & $42+x$ & 12 & 45 & 22 & 14 \\
\hline 49759 & $"$ & $\sigma^{x}$ & $30+35$ & 12 & - & - & 14 \\
\hline
\end{tabular}


APPENDIX - RAW DATA ( continuation )

\begin{tabular}{|c|c|c|c|c|c|c|c|}
\hline \multirow[t]{2}{*}{ MZUSP } & \multirow{2}{*}{ Locality } & \multirow{2}{*}{ Sex } & \multirow{2}{*}{ Lenght } & \multicolumn{2}{|c|}{ Tubercles } & \multirow{2}{*}{ Ventr. } & \multirow[t]{2}{*}{ Lam. } \\
\hline & & & & $\operatorname{trv}$ & $\operatorname{lgt}$ & & \\
\hline \multicolumn{2}{|c|}{ Pernambuco } & & & & & & \\
\hline 49761 & Exu & $\sigma^{x}$ & $34+43$ & 12 & 48 & 21 & 16 \\
\hline 49762 & " & $\sigma^{7}$ & $36+43$ & 12 & 47 & 21 & 15 \\
\hline 49763 & $"$ & 우 & $30+x$ & 12 & 44 & 21 & 16 \\
\hline 49764 & " & 우 & $29+x$ & 12 & 47 & 20 & 15 \\
\hline 49765 & " & q & $29+x$ & 12 & 42 & 20 & 15 \\
\hline 49766 & $"$ & $\sigma^{\pi}$ & $30+38$ & 12 & - & - & 14 \\
\hline 49767 & $"$ & $\sigma^{\pi}$ & $32+44$ & - & 44 & - & 14 \\
\hline 49768 & " & $\sigma^{7}$ & $38+x$ & 12 & - & 22 & 15 \\
\hline 49770 & $"$ & $\sigma^{x}$ & $41+x$ & 12 & 45 & 21 & 14 \\
\hline 49771 & $"$ & 우 & $24+28$ & 12 & 46 & 18 & 14 \\
\hline 49772 & " & q & $24+28$ & 12 & 46 & 19 & 14 \\
\hline 49773 & $"$ & 우 & $23+28$ & 12 & 46 & 19 & 14 \\
\hline 49774 & " & $\sigma^{\pi}$ & $41+x$ & 12 & - & 21 & 14 \\
\hline 49776 & " & q & $30+36$ & 12 & 41 & - & - \\
\hline 49777 & $"$ & $\sigma^{x}$ & $42+x$ & 12 & - & 21 & 14 \\
\hline 49779 & " & $\sigma^{\pi}$ & $41+x$ & 12 & 44 & 21 & 14 \\
\hline 49781 & $"$ & $\sigma^{\pi}$ & $25+28$ & - & 44 & - & 14 \\
\hline 49783 & $"$ & $\sigma^{x}$ & $29+x$ & 12 & 47 & - & 14 \\
\hline 49784 & $"$ & q & $22+31$ & - & - & - & 14 \\
\hline 49785 & $"$ & $\sigma^{x}$ & $40+x$ & 12 & - & - & 14 \\
\hline 49786 & $"$ & $\sigma^{\pi}$ & $41+x$ & 12 & 44 & 20 & 14 \\
\hline 49787 & $"$ & 우 & $41+x$ & 12 & - & 21 & - \\
\hline 49788 & " & 우 & $42+x$ & 12 & 45 & - & 15 \\
\hline 49789 & " & q & $41+x$ & 12 & 42 & 19 & 14 \\
\hline 49790 & $"$ & $\sigma^{\pi}$ & $41+x$ & - & 42 & - & - \\
\hline 49791 & " & q & $42+x$ & 12 & 44 & 22 & 15 \\
\hline 49792 & " & 우 & $40+x$ & 12 & 47 & - & 14 \\
\hline 49794 & " & $0^{x}$ & $37+40$ & 12 & 48 & 19 & 15 \\
\hline 49795 & $"$ & $\sigma^{x}$ & $29+x$ & 12 & 39 & 19 & 16 \\
\hline 49796 & $"$ & $\sigma^{\pi}$ & $20+x$ & 12 & 43 & - & 15 \\
\hline 49797 & $"$ & $\sigma^{\pi}$ & $21+25$ & 12 & - & - & 14 \\
\hline 49798 & " & q & $43+x$ & 12 & 44 & 22 & 14 \\
\hline 49799 & " & 우 & $41+x$ & 12 & 47 & 22 & 16 \\
\hline 49800 & " & 우 & $39+47$ & 12 & 40 & 21 & 14 \\
\hline 49801 & " & $\sigma^{7}$ & $38+x$ & 12 & 44 & 21 & 16 \\
\hline 49802 & $"$ & $\sigma^{\pi}$ & $22+26$ & 12 & 46 & - & 16 \\
\hline
\end{tabular}


APPENDIX - RAW DATA ( continuation )

\begin{tabular}{|c|c|c|c|c|c|c|c|}
\hline \multirow[t]{2}{*}{ MZUSP } & \multirow{2}{*}{ Locality } & \multirow{2}{*}{ Sex } & \multirow{2}{*}{ Lenght } & \multicolumn{2}{|c|}{ Tubercles } & \multirow[t]{2}{*}{ Ventr. } & \multirow[t]{2}{*}{ Lam. } \\
\hline & & & & $\operatorname{trv}$ & $\operatorname{lgt}$ & & \\
\hline \multicolumn{2}{|c|}{ Pernambuco } & & & & & & \\
\hline 49803 & Exu & q & $24+27$ & 12 & 49 & 21 & 15 \\
\hline 49804 & " & q & $22+25$ & 12 & - & - & 15 \\
\hline 49805 & $"$ & 우 & $19+25$ & 12 & 47 & 20 & - \\
\hline 49806 & " & o & $20+25$ & 12 & - & - & 14 \\
\hline 49807 & $"$ & $\sigma^{x}$ & $20+26$ & - & - & - & - \\
\hline 49808 & $"$ & $\sigma^{x}$ & $25+x$ & 12 & 42 & - & 13 \\
\hline 49809 & $"$ & q & $38+x$ & 12 & - & 20 & 18 \\
\hline 49810 & $"$ & 우 & $36+41$ & 12 & 43 & 22 & 18 \\
\hline 49811 & $"$ & 우 & $39+x$ & 12 & 45 & 21 & 17 \\
\hline 49812 & " & $0^{7}$ & $42+x$ & 12 & 43 & 20 & 14 \\
\hline 49813 & Exu & ㅇ & $35+x$ & 12 & 44 & 20 & 16 \\
\hline 49814 & " & q & $33+42$ & - & - & 20 & - \\
\hline 49815 & $"$ & $\sigma^{x}$ & $38+x$ & 12 & - & 12 & 19 \\
\hline 49816 & $"$ & ㅇ & $42+x$ & 12 & 42 & - & 15 \\
\hline 49817 & $"$ & $0^{x}$ & $37+x$ & 12 & 42 & - & 14 \\
\hline 49818 & $"$ & ㅇ & $23=28$ & 12 & 42 & - & 14 \\
\hline 49819 & $"$ & 우 & $37+x$ & 12 & 43 & 19 & 17 \\
\hline 49820 & $"$ & 우 & $40+45$ & 12 & - & 20 & 17 \\
\hline 49821 & $"$ & 우 & $38+x$ & 12 & 47 & - & 15 \\
\hline 49822 & $"$ & $\sigma^{7}$ & $22+33$ & 12 & 41 & - & 14 \\
\hline 49823 & $"$ & q & $40+x$ & 12 & 42 & - & - \\
\hline 49824 & " & 우 & $37+x$ & 12 & 43 & 20 & 16 \\
\hline 49825 & $"$ & q & $42+x$ & 12 & 46 & 20 & 16 \\
\hline 49826 & $"$ & 우 & $41+x$ & 12 & 51 & 20 & 16 \\
\hline 49827 & " & 우 & $43+x$ & 12 & 37 & 19 & 14 \\
\hline 49828 & $"$ & 우 & $47+x$ & 12 & 44 & 19 & - \\
\hline 49829 & $"$ & $\mathrm{j}$ & $25+31$ & - & - & - & 17 \\
\hline 49831 & $"$ & $\sigma^{x}$ & $43+x$ & 12 & 45 & - & 18 \\
\hline 49832 & $"$ & q & $45+x$ & 12 & 46 & 22 & 17 \\
\hline 49835 & $"$ & $\mathrm{j}$ & $21=24$ & 12 & 45 & 22 & 17 \\
\hline 49837 & $"$ & $\sigma^{x}$ & $40+53$ & 12 & 43 & 20 & 17 \\
\hline 49839 & " & 우 & $28+32$ & 12 & 42 & 22 & 17 \\
\hline 49840 & " & 우 & $38+x$ & 12 & 48 & - & - \\
\hline 49841 & $"$ & 우 & $44+x$ & 12 & 45 & 24 & 17 \\
\hline
\end{tabular}


APPENDIX - RAW DATA ( continuation )

\begin{tabular}{|c|c|c|c|c|c|c|c|}
\hline \multirow[t]{2}{*}{ MZUSP } & \multirow[t]{2}{*}{ Locality } & \multirow[t]{2}{*}{ Sex } & \multirow[t]{2}{*}{ Lenght } & \multicolumn{2}{|c|}{ Tubercles } & \multirow{2}{*}{ Ventr. } & \multirow[t]{2}{*}{ Lam. } \\
\hline & & & & $\operatorname{trv}$ & $\operatorname{lgt}$ & & \\
\hline \multicolumn{2}{|c|}{ Perna mbuco } & & & & & & \\
\hline 49842 & Exu & q & $41+x$ & 12 & 48 & - & 17 \\
\hline 49843 & " & $\sigma^{\pi}$ & $36+x$ & 12 & 46 & 22 & 17 \\
\hline 49845 & " & q & $40+x$ & 12 & 44 & 19 & 16 \\
\hline 49846 & $"$ & $\sigma^{\pi}$ & $42+x$ & 12 & - & 22 & - \\
\hline 49847 & " & 운 & $33+x$ & 12 & 44 & - & 16 \\
\hline 49848 & " & q & $33+x$ & 12 & 45 & 21 & - \\
\hline 49849 & $"$ & 우 & $33+x$ & 12 & 44 & - & 16 \\
\hline 49850 & $"$ & q & $35+x$ & - & - & - & 15 \\
\hline \multicolumn{2}{|c|}{ A lagoas } & & & & & & \\
\hline 78920 & Xingó & $\mathrm{j}$ & $29+31$ & 12 & 44 & 22 & 15 \\
\hline 79821 & " & $\mathrm{j}$ & $33+x$ & 12 & 48 & 21 & 15 \\
\hline 79822 & " & $\sigma^{x}$ & $37+x$ & 12 & 45 & 23 & 16 \\
\hline 78923 & " & $\mathrm{j}$ & $30+31$ & 12 & 52 & 19 & 15 \\
\hline 78924 & $"$ & $\mathrm{~J}$ & $38+x$ & 12 & 52 & 24 & 14 \\
\hline 78925 & " & $\mathrm{j}$ & $31+32$ & 12 & 51 & 21 & 17 \\
\hline 78926 & $"$ & $\mathrm{j}$ & $32+x$ & 12 & 51 & 20 & 15 \\
\hline 78932 & $"$ & $\mathrm{j}$ & $35+x$ & 12 & - & - & 15 \\
\hline 79008 & $"$ & $\mathrm{j}$ & $35+46$ & 12 & - & 22 & 14 \\
\hline 79009 & " & 우 & $40+x$ & 12 & 53 & 24 & 15 \\
\hline 79010 & $"$ & $\mathrm{j}$ & $30+32$ & 12 & - & 24 & 15 \\
\hline 79011 & $"$ & $0^{x}$ & $40+x$ & 12 & 42 & 21 & 15 \\
\hline 79012 & " & $\mathrm{j}$ & $33+x$ & 12 & 49 & 24 & 14 \\
\hline 79013 & $"$ & $\mathrm{j}$ & $35+x$ & 12 & 57 & 24 & 14 \\
\hline 79014 & " & $\sigma^{\pi}$ & $39+x$ & 12 & 48 & 21 & 14 \\
\hline 79015 & " & $\sigma^{x}$ & $39+x$ & 12 & 46 & 22 & 15 \\
\hline 79016 & " & $\sigma^{x}$ & $40+49$ & 12 & 48 & 20 & 13 \\
\hline 79017 & $"$ & $\mathrm{j}$ & $38+x$ & 12 & 42 & 22 & 15 \\
\hline 91687 & " & $\mathrm{j}$ & $37+45$ & 12 & 48 & 19 & 16 \\
\hline \multicolumn{2}{|l|}{ Bahia } & & & & & & \\
\hline 75487 & \multirow[t]{2}{*}{ Barra } & $\sigma^{x}$ & $45+x$ & - & - & - & 17 \\
\hline 75488 & & $\sigma^{x}$ & $41+44$ & 12 & 44 & 20 & 16 \\
\hline 75489 & " & $\mathrm{j}$ & $21+21$ & 12 & 45 & 22 & - \\
\hline 75490 & $"$ & 우 & $42+x$ & - & 47 & 22 & 15 \\
\hline 75491 & $"$ & $\mathrm{j}$ & $24+x$ & 12 & 45 & 20 & 17 \\
\hline 75496 & $"$ & $\sigma^{7}$ & $42+52$ & 12 & 46 & 20 & 18 \\
\hline 71918 & Vacaria & $\sigma^{7}$ & $40+x$ & 12 & 51 & 21 & 16 \\
\hline 75458 & " & $\mathrm{j}$ & $33+x$ & 12 & 50 & 22 & 16 \\
\hline
\end{tabular}


APPENDIX - RAW DATA ( continuation )

\begin{tabular}{|c|c|c|c|c|c|c|c|}
\hline \multirow[t]{2}{*}{ MZUSP } & \multirow[t]{2}{*}{ Locality } & \multirow[t]{2}{*}{ Sex } & \multirow[t]{2}{*}{ Lenght } & \multicolumn{2}{|c|}{ Tubercles } & \multirow[t]{2}{*}{ Ventr. } & \multirow[t]{2}{*}{ Lam. } \\
\hline & & & & $\operatorname{trv}$ & $\operatorname{lgt}$ & & \\
\hline \multicolumn{2}{|l|}{ B a h i a } & & & & & & \\
\hline 75459 & Vacaria & $\mathrm{j}$ & $19+x$ & 12 & 50 & 22 & 16 \\
\hline 76266 & Xiquexique & $\mathrm{j}$ & $23+x$ & 12 & 45 & 20 & - \\
\hline 62760 & Raso da Catarina & 우 & $42+x$ & 12 & 45 & 24 & \\
\hline 62761 & " & $\mathrm{j}$ & $35+x$ & 12 & 44 & 20 & 17 \\
\hline 62762 & $"$ & $0^{7}$ & $42+x$ & 12 & - & 19 & 16 \\
\hline 62763 & $"$ & $\mathrm{j}$ & $37+x$ & 12 & 43 & 22 & 17 \\
\hline 62764 & $"$ & $\mathrm{j}$ & $37+x$ & 12 & 47 & 24 & 17 \\
\hline 62765 & $"$ & $\mathrm{j}$ & $30+x$ & 12 & 44 & 20 & 15 \\
\hline 65804 & $"$ & $\mathrm{j}$ & $37+48$ & 12 & 41 & 21 & 16 \\
\hline 65805 & $"$ & $\mathrm{j}$ & $34+x$ & 12 & 43 & 21 & 16 \\
\hline 65806 & $"$ & $\mathrm{j}$ & $36+x$ & 12 & 47 & 21 & 17 \\
\hline 65807 & $"$ & $\mathrm{j}$ & $35+35$ & - & - & 20 & 17 \\
\hline 408 & Senhor do Bonfim & o & $39+x$ & 12 & 41 & - & 18 \\
\hline 457 & " & $\mathrm{j}$ & $36+x$ & 12 & 41 & - & 15 \\
\hline 658 & $"$ & $0^{7}$ & $40+x$ & 12 & 45 & 21 & 16 \\
\hline 12299 & $"$ & q & $42+x$ & 12 & 44 & 22 & 16 \\
\hline 12301 & $"$ & $\mathrm{j}$ & $34+x$ & 12 & 49 & 20 & 18 \\
\hline 54974 & Caatinga do Moura & $0^{7}$ & $44+x$ & 12 & 46 & 19 & 17 \\
\hline 54975 & " & $\mathrm{j}$ & $37+44$ & 12 & - & 23 & 17 \\
\hline 54976 & " & $\mathrm{j}$ & $27+x$ & 12 & 48 & 22 & 17 \\
\hline 54977 & $"$ & $\mathrm{j}$ & $24+x$ & 12 & 42 & 20 & 17 \\
\hline 54978 & $"$ & $\mathrm{j}$ & $39+x$ & 12 & 41 & 22 & 16 \\
\hline 54979 & $"$ & $\mathrm{j}$ & $34+x$ & 12 & 42 & 21 & 16 \\
\hline 54980 & $"$ & $\sigma^{x}$ & $36+x$ & 12 & 44 & 20 & 17 \\
\hline 54981 & $"$ & 우 & $40+x$ & 12 & 42 & 22 & 17 \\
\hline 54982 & $"$ & $\sigma^{7}$ & $41+x$ & 12 & 46 & 20 & 17 \\
\hline 54983 & $"$ & $\mathrm{j}$ & $24+32$ & 12 & 46 & 22 & 17 \\
\hline 54987 & $"$ & $\mathrm{j}$ & $36+47$ & 12 & 45 & 22 & 16 \\
\hline 54988 & $"$ & $\mathrm{j}$ & $33+41$ & 12 & 42 & 20 & 16 \\
\hline 54989 & " & $\sigma^{x}$ & $41+x$ & 12 & 41 & 22 & 16 \\
\hline 54991 & " & $\mathrm{j}$ & $26+31$ & 12 & 42 & 22 & - \\
\hline 54992 & " & $\mathrm{j}$ & $31+36$ & 12 & 44 & 20 & 17 \\
\hline 54993 & " & $0^{7}$ & $42+x$ & 12 & 46 & 21 & 16 \\
\hline 54994 & $"$ & 우 & $42+53$ & 12 & 47 & - & 18 \\
\hline 54999 & " & 우 & $39+x$ & 12 & 43 & 19 & 18 \\
\hline 55003 & " & $\sigma^{\pi}$ & $42+x$ & 12 & 39 & 20 & 18 \\
\hline 55004 & $"$ & $q$ & $43+x$ & 12 & 44 & 20 & - \\
\hline
\end{tabular}


APPENDIX - RAW DATA ( continuation )

\begin{tabular}{|c|c|c|c|c|c|c|c|}
\hline \multirow[t]{2}{*}{ MZUSP } & \multirow[t]{2}{*}{ Locality } & \multirow[t]{2}{*}{ Sex } & \multirow[t]{2}{*}{ Lenght } & \multicolumn{2}{|c|}{ Tubercles } & \multirow[t]{2}{*}{ Ventr. } & \multirow[t]{2}{*}{ Lam. } \\
\hline & & & & $\operatorname{trv}$ & lgt & & \\
\hline \multicolumn{2}{|l|}{ B a h i a } & & & & & & \\
\hline 55006 & Caatinga do Moura & $\sigma^{7}$ & $41+x$ & 12 & 47 & 22 & 18 \\
\hline 55007 & " & $\mathrm{j}$ & $23+25$ & 12 & - & 23 & 16 \\
\hline 55009 & $"$ & $\sigma^{\pi}$ & $39+44$ & 12 & 46 & 23 & 17 \\
\hline 55010 & " & $\mathrm{j}$ & $30+x$ & 12 & 41 & 22 & 16 \\
\hline 55011 & " & $\mathrm{j}$ & $29+31$ & 12 & 42 & 20 & 17 \\
\hline 55013 & " & $\mathrm{j}$ & $27+x$ & 12 & - & 20 & 17 \\
\hline 55014 & $"$ & 우 & $40+48$ & 12 & 44 & 20 & 18 \\
\hline 62788 & Morro do Chapéu & $\sigma^{\pi}$ & $42+50$ & 12 & 43 & 22 & 17 \\
\hline 62790 & " & 우 & $40+x$ & 12 & 44 & 24 & 16 \\
\hline 62791 & " & 우 & $42+x$ & 12 & 45 & 23 & 17 \\
\hline 65764 & " & $\mathrm{j}$ & $29+x$ & & 45 & 20 & - \\
\hline 65765 & $"$ & q & $40+45$ & 12 & 41 & 22 & 16 \\
\hline 65786 & " & $\mathrm{j}$ & $38+42$ & 12 & 40 & 22 & 18 \\
\hline 73910 & " & $\mathrm{j}$ & $37+x$ & 12 & - & 24 & 18 \\
\hline 73911 & " & $\sigma^{\pi}$ & $39+53$ & 12 & 39 & 20 & 18 \\
\hline 73912 & $"$ & $\mathrm{j}$ & $25+x$ & - & - & 22 & - \\
\hline 73913 & Morro do Chapéu & $\mathrm{j}$ & $27+x$ & 12 & - & 24 & 18 \\
\hline 73914 & " & $\mathrm{j}$ & $30+x$ & 12 & 44 & 22 & 16 \\
\hline 73915 & $"$ & q & $45+44$ & 12 & - & - & 19 \\
\hline 73916 & " & $\sigma^{\pi}$ & $40+x$ & 12 & 39 & - & 19 \\
\hline 73917 & $"$ & o & $40+x$ & 12 & 37 & - & 17 \\
\hline 73918 & " & $\sigma^{\pi}$ & $42+x$ & 12 & 36 & 22 & 17 \\
\hline 73919 & " & $\sigma^{x}$ & $40+x$ & 12 & 39 & - & 17 \\
\hline 73920 & " & $\sigma^{7}$ & $40+x$ & 12 & 36 & - & 18 \\
\hline 73921 & " & $\sigma^{\pi}$ & $41+x$ & 12 & - & - & 17 \\
\hline 73922 & $"$ & $\mathrm{j}$ & $37+x$ & 12 & 43 & - & 17 \\
\hline 73923 & $"$ & q & $41+x$ & 12 & 37 & - & 18 \\
\hline 73924 & " & $\sigma^{x}$ & $42+x$ & 12 & 38 & 22 & 18 \\
\hline 73925 & $"$ & $\sigma^{\pi}$ & $452+x$ & 12 & 38 & 24 & 19 \\
\hline 56290 & Mucugê & ㅇ & $41+50$ & 12 & 32 & 22 & 18 \\
\hline 56291 & " & q & $49+x$ & 12 & 33 & 17 & 18 \\
\hline 68285 & $"$ & 우 & $47+57$ & 12 & 34 & 22 & 20 \\
\hline 68286 & $"$ & ㅇ & $51+70$ & 12 & 33 & 20 & 17 \\
\hline 73926 & $"$ & $\mathrm{j}$ & $30+x$ & 12 & 32 & - & 19 \\
\hline 73927 & $"$ & $\mathrm{j}$ & $37+x$ & 12 & 36 & - & 19 \\
\hline 73928 & $"$ & $0^{x}$ & $45+x$ & 12 & - & - & 17 \\
\hline
\end{tabular}


APPENDIX - RAW DATA ( continuation )

\begin{tabular}{|c|c|c|c|c|c|c|c|}
\hline \multirow{2}{*}{ MZUSP } & \multirow[t]{2}{*}{ Locality } & \multirow[t]{2}{*}{ Sex } & \multirow[t]{2}{*}{ Lenght } & \multicolumn{2}{|c|}{ Tubercles } & \multirow[t]{2}{*}{ Ventr. } & \multirow[t]{2}{*}{ Lam. } \\
\hline & & & & $\operatorname{trv}$ & $\operatorname{lgt}$ & & \\
\hline \multicolumn{2}{|l|}{ Bah i a } & & & & & & \\
\hline 92227 & Salvador & $\mathrm{j}$ & $28+30$ & 12 & 44 & 20 & 19 \\
\hline 92228 & " & $\sigma^{7}$ & $40+x$ & 12 & 49 & 20 & 17 \\
\hline 92229 & $"$ & q & $40+x$ & 12 & 42 & 22 & 17 \\
\hline 92230 & " & $\sigma^{x}$ & $40+x$ & 12 & 46 & 22 & 18 \\
\hline 92231 & $"$ & $\mathrm{j}$ & $34+x$ & 12 & 48 & 24 & 18 \\
\hline 92232 & $"$ & $0^{7}$ & $36+37$ & 12 & 46 & 24 & 19 \\
\hline 92233 & $"$ & $\sigma^{7}$ & $43+47$ & 12 & 46 & 22 & 18 \\
\hline
\end{tabular}

\section{ACKNOWLEDGMENTS}

W. Ronald Heyer (National Museum of Natural History, Smithsonian Institution) and C.W. Myers (American Museum of Natural History) very profitably criticized an early draft of the manuscript. Dr. Colin McCarthy provided valuable information on British Museum specimens. The Museu de Zoologia library staff, and especially Dione Seripierri, as well as Lina Maria Castro Trigo (Salvador, Bahia), were invaluable in obtaining refractory literature. The graphs were drawn by Francisca Carolina do Val and Pablo Rodrigo B. Oñate. Maria da Conceição Bueno da Silva scanned the figures. Carolina Castro-Mello (who took the photographs) and Celso Morato de Carvalho (who collected the essential sample from Salvador), additionally helped in many ways at all stages.

This work was not supported by any granting agency.

\section{RESUMO}

O conceito específico de G. geckoides foi firmado com base em uma amostra topotípica de Salvador, Bahia. A diferenciação geográfica da espécie foi estudada através da análise de dois caracteres merísticos (número de tubérculos em uma fileira paramediana e de lamelas do quarto artelho) e do padrão de colorido. Ficou claro que a amostra de Mucugê, Bahia, diverge fortemente das demais em todos os caracteres estudados. É proposto um modelo de diferenciação em refugio holocênico para explicar esse padrão. Fica adiada a decisão sobre o status taxonômico da população de Mucugê para quando se tenha melhor amostragem geográfica e possam ser aplicadas técnicas moleculares.

Palavras-chave: especiação, refúgios holocênicos; lagartos: ecologia; lagartos: sistemática.

\section{REFERENCES}

AB'SÁber AN. 1955. O planalto da Borborema, na Paraíba. Bol Paulista Geogr 13: 55-56.

Aв'SÁBer AN. 1956. Depressões periféricas e depressões semi-áridas no Nordeste do Brasil. Bol Paulista Geogr 22: 3-18.

Aв’SÁBER AN. 1967. Domínios morfoclimáticos e províncias fitogeográficas do Brasil. Orientação (Dep Geogr Univ S Paulo) 3: 45-48.

Aв’SÁber AN. 1969. Participação das superfícies aplainadas nas paisagens do Nordeste brasileiro. Geomorfologia (Inst Geogr Univ S Paulo) 19: 1-38.

Aв’SÁbER AN. 1977a. Espaços ocupados pela expansão dos climas secos na América do Sul, por ocasião dos períodos glaciais quaternários. Paleoclimas (Inst Geogr Univ S Paulo) 3: 1-19, map.

Aв’SÁBER AN. 1977b. Os domínios morfoclimáticos na América do Sul. Primeira aproximação. Geomorfologia (Inst Geogr Univ S Paulo) 52: 1-21.

Ав'SÁber AN. 2003. Os domínios de natureza no Brasil. Potencialidades paisagísticas. S. Paulo: Ateliê Editorial. $159 \mathrm{p}$.

Amaral A. 1923. New genera and species of snakes. Proc. New England Zool Club 8: 85-05. 
Amaral A. 1933. Estudos sôbre lacertílios neotrópicos I. Novos gêneros e espécies de lagartos do Brasil. Mem Inst Butantan 7: 51-74, pls.

Amaral A. 1934. Collecta herpetologica no Nordeste do Brasil. Mem Inst Butantan 8: 185-192.

Amaral A. 1935a. Collecta herpetologica no Nordeste do Brasil (Contribuição II). Mem Inst Butantan 9: 227-232.

Amaral A. 1935b. Collecta herpetologica no centro do Brasil. Mem Inst Butantan 9: 235-246.

Amaral A. 1950. Two new South American lizards. Copeia 1950 (4): 281-284.

Andrade-Lima D. 1981. The Caatingas Dominium. Rev Brasil Bot 4: 149-163.

Azevedo LMP And Moreira RC. 1981. Uso potencial da terra. Climatologia, p. 706-728 in Projeto Radambrasil, Levantamento de Recursos Naturais vol. 23 .

BAHIA SEI (SuperintendÊNCIA DE Estudos EconôMICOS E SociaIs). 1998. Atributos climáticos do Estado da Bahia. Salvador. 85p., maps. Série Estudos e Pesquisas 38.

BAHIA SEI (SuperintendÊNCIA DE Estudos EconôMicos E SociaIs). 1999. Balanço hídrico do Estado da Bahia. Salvador. 249p. Série Estudos e Pesquisas 45 .

BAILEY RG. 1998. Ecoregions: the ecosystem geography of the oceans and continents. New York etc.: Springer-Verlag. 176p.

Barbour T. 1925. New Neotropical lizards. Proc Biol Soc Washington 38: 101-102.

BoIE H. 1826. Bemerkungen ueber die von Hr. von Spix abgebildeten Saurier. Isis von Oken 18: 117-120.

Boulenger GA. 1885. Catalogue of the lizards in the British Museum (Natural History). Vol. I. London: Trustees of the British Museum. xii + 436p., pls.

BrazÃo JEM and Araujo AP. 1981. Vegetação. As regiões fitogeográficas, sua natureza e seus recursos econômicos. Estudo fitogeográfico. p. 405-464 in Projeto Radambrasil, Levantamento de Recursos Naturais, vol. 24.

Cuvier G. 1829. Le règne animal distribué d'après son organisation... Nouvelle édition. Tome II. Paris: Deterville, Crochard. $\mathrm{xv}+406 \mathrm{p}$.
Dixon WJ AND MASSEY FJ. 1983. Introduction to statistical analysis. Fourth edition. New York etc.: McGraw Hill. $\mathrm{xv}+678 \mathrm{p}$.

Dresch J. 1957. Les problèmes morphologiques du Nord'Est brésilien. Bull Ass Géogr France 263-264: 48-59 [transcribed in Bol Geogr Cons Nac Geogr 20 (166): 1962].

Duméril AMC and Bibron G. 1836. Erpétologie Générale ou Histoire Naturelle Complète des Reptiles. Vol. 3. Paris: Roret. iv $+517 \mathrm{p}$.

DuvernOY GL. 1836-1842. Les reptiles, avec un atlas, in Le règne animal... par Georges Cuvier, édition... par une reúnion de disciples de Cuvier... Paris: Fortin, Masson. 162p., pls. (see Vanzolini 1977).

Fitzinger L. 1826. Neue Classification der Reptilien nach ihren natürlichen Verwandschaften nebst einer Verwandschaft-Tafel und eine Verzeichnisse der Reptilien - Sammlung des K.K. zoologichen Museum zu Wien. Vienna: J.G. Heubner. 66 p. (fac-simile reprint, 1997, Society for the Study of Amphibians and Reptiles).

FitZINGER L. 1827. Recension des Spixischen Eidechsenwerkes. Isis von Oken 20: 741-750.

Fitzinger L. 1843. Systema Reptilium. Fasciculus primus, Amblyglossae. Vienna: Braumüller et Seidel. 106p. (fac-simile reprint 1973, Society for the Study of Amphibians and Reptiles).

FreIRE EMX. 1996. Estudo ecológico e zogeográfico sobre a fauna de lagartos (Sauria) das dunas de Natal, Rio Grande do Norte e da restinga de Ponta da Campina, Cabedelo, Paraíba, Brasil. Rev. Brasil Zool 13: 903-921.

FreIRE EMX. 1998. Diferenciação geográfica em Gymnodactylus darwinii (Gray 1845) (Sauria, Gekkonidae). Papéis Avulsos Zool. 40(20): 311-322.

FreIRE-SouzA EM. 1991. Gymnodactylus geckoides e Gymnodactylus darwinii em simpatria nas dunas de Natal-RN (Sauria, Gekkonidae). Resumos XVIII Congr Brasil Zool: 347.

Giulietti AM and Pirani JR. 1988. Patterns of geographic distribution of some plant species from the Espinhaço Range, Minas Gerais and Bahia, Brazil, p. 39-69 in Vanzolini PE and Heyer WR (eds.) Proceeedings of a workshop on Neotropical distributional patterns. 
GoEldi E. 1902. Lagartos do Brazil. Bol Mus Paraense 3: 370-399.

Gonçalves LMC and ORLANDi RS. 1983. Vegetação. As regiões fitoecológicas, sua natureza e seus recursos econômicos. Estudo fitogeográfico, p. 573-639 in Projeto Radambrasil, Levantamento de Recursos Naturais, vol. 30.

Gray JE. 1831. A synopsis of the Class Reptilia. 110p., Appendix to Griffith E. The animal kingdom... by Baron Cuvier, with additional description of all species hitherto named, and of many not before noticed. Vol. 9. London: Whittaker, Teacher.

GRAY JE. 1845. Catalogue of the specimens of lizards in the collection of the British Museum. London: Trustees of the British Museum. xxviii + 289p.

GRIFFIN LE. 1917. A list of South American lizards of the Carnegie Museum, with description of four new species. Ann Carnegie Mus 11: 304-320, pls.

Grillo AAS. 2000. Aspectos pedológicos, ecológicos e florísticos de uma área de cerrado no município de Palmeiras, Chapada Diamantina, Bahia. Master's dissertation, Dept Botanica, Univ S Paulo. 225p.

Harley RM. 1995. Introduction. p. 1-40 in StanNARD BL. ed., Flora of the Pico das Almas, Chapada Diamantina - Bahia, Brazil.

HaRley RM AND Simmons NA. 1986. Florula of Mucugê, Chapada Diamantina Bahia, Brazil. Kew: Royal Botanical Gardens. $x i+227 p$.

Heyer WR. 1999. A new genus and species of frog from Bahia, Brazil (Amphibia: Anura: Leptodactylidae) with comments on the zoogeography of the Brazilian campos rupestres. Proc Biol Soc Washington 112 (1): 19-39.

Hoogmoed MS and Gruber U. 1983. Spix and Wagler type specimens of reptiles and amphibians in the natural history musea in Munich (Germany). and Leiden (The Netherlands). Spixiana Suppl 9: 319-415.

IgLesias FA. 1951. Caatingas e chapadões (Notas, impressões e reminiscências do Meio Norte brasileiro). S. Paulo: Companhia Editora Nacional. Brasiliana vol. 271. $\mathrm{xxv}+638 \mathrm{p}$.

Kluge AG. 1993. Gekkonoid lizard taxonomy. San Diego, California: International Gecko Society. $245 p$.

Ledru MP, Behling H, Fournier M, Martin L AND
Servant M. 1994. Localisation de la forêt d'Araucaria du Brésil au cours de l'Holocène, implications paléoclimatiques. CR Acad Sci Paris (Sciences de la Vie) 317: 517-521.

Ledru MP, Braga PIS, Soubiès F, Fournier M, Martin L, Suguio K and Turce B. 1996. The last 50,000 years in the Neotropics (Southern Brazil): evolution of vegetation and climate. Palaeogogr Palaeoclimat Palaeoecol 123: 239-257.

Ledru MP, SAlgado-Labouriau ML and LorscheitTER ML. 1998. Vegetation dynamics in Southern and Central Brazil during the last 10,000 yr. B.P. Rev Palaeobot Palyn 99: 131-142.

Nimer E. 1979. Pluviometria e recursos hídricos de Pernambuco e Paraíba. IBGE (Fundação Instituto Brasileiro de Geografia e Estatística), Série Recursos Naturais e Meio Ambiente 3. 117p.

Oliveira PE, Barreto AMF and Suguio K. 1999. Late Pleistocene/Holocene climatic and vegetational history of the Brazilian caatinga: the fossil dunes of the middle São Francisco River. Palaeogeogr Palaeoclimat Palaeoecol 152: 319-337.

Pellegrino KCM. 1998. Diversidade cariotípica e evolução cromossômica em lagartos das famílias Gymnophthalmidae e Gekkonidae (Squamata): evidências baseadas em coloração diferencial e hibridação in situ fluorescente (FISH). Doctoral thesis, Instituto de Biociências, Univ S Paulo (6) + 137p.

Peters W. 1877. Herpetologische Notizen I. Über die von Spix in Brasilien gesammelten Eidechsen des Naturalien - Kabinets zu München. Monatsber. Akad Wiss Berlin 1877: 407-414.

Pielou EC. 1979. Biogeography. New York etc.: John Wiley \& Sons. ix $+351 p$.

Prado DE and Gibbs PE. 1993. Patterns of species distributions in the dry seasonal forests of South America. Ann Missouri Bot Gard 80: 902-927.

Projeto Radambrasil. 1975. Levantamento de recursos naturais. Vol. 8, Folha NA.20 Boa Vista e parte das Folhas NA.21 Tumucumaque, NB.20 Roraima e NB.21. Rio de Janeiro: Ministério das Minas e Energia. 403p., pls.

Projeto Radambrasil. 1981a. Levantamento de Recursos Naturais. Vol. 23, Folhas SB.24/25 Jaguaribe/ Natal. Rio de Janeiro: Ministério das Minas e Energia. 739p. 
Projeto Radambrasil. 1981b. Levantamento de Recursos Naturais. Vol. 24, Folha SD.24 Salvador. Rio de Janeiro: Ministério das Minas e Energia. 620p., pls.

Projeto Radambrasil. 1983. Levantamento de Recursos Naturais. Vol. 30. Folhas SC.24/25 Aracaju/ Recife. Rio de Janeiro: Ministério das Minas e Energia. 839 p., pls.

Rodrigues MT. 1987. Sistemática, ecologia e zoogeografia dos Tropidurus do grupo torquatus ao sul do Rio Amazonas. Arq Zool, S Paulo 31 (3): 105-230.

ScHINZ HR. 1833-1835. Naturgeschichte und Abbildungen der Reptilien. Leipzig: Wiedmann. $250+$ iv p., pls. (for dates see Vanzolini 1977: 48).

SCHMidT KP AND Inger RF. 1951. Amphibians and reptiles of the Hopkins-Branner Expedition to Brazil. Fieldiana Zool 31 (42): 439-465.

Seabra GF. 1998. Dos garimpos aos ecos do turismo: o Parque Nacional da Chapada Diamantina. Doctoral thesis, Dept. Geografia, Univ. S. Paulo.

SICK H. 1984. Ornitologia brasileira, uma introdução. Vol. 1. 3a. edição. Brasília: Editora Universidade de Brasília. xix $+828 p$.

SpIX JB. 1824. Species novae testudinum quas in itinere annis MDCCCXVII-MDCCCXX per Brasiliam... collegit et descripsit... Munich: C.V.F.P. de Martius. 24 p., pls.

SPIX JB. 1825. Animalia nova sive species novae lacertarum quas in itinere per Brasiliam annis MDCCCXVII-MDCCCXX jussu et auspiciis Maximiliani Josephi I. Bavierae Regis suscepto collegit et descripsit Dr. J.B. de Spix. Munich: F.S. Hubshmann. 26p., pls.

Stannard BL., ED. 1995. Flora of the Pico das Almas, Chapada Diamantina-Bahia, Brazil. Kew, UK: Royal Botanical Gardens. xxiv $+853 p$.

STeindachner F. 1867. Reise der österreichichen Fregatte Novara um die Erden in den Jahren 1857, 1858, 1859. Zoologischer Theil. Erster Band (Wirbelthiere) - 3. Reptilien. Vienna: K.K. Hof- und Staatsdruckerei 98p., pls.

Steindachner F. 1870. Herpetologische Notizen (II). II. Über einige neue oder seltene Reptilien des Wiener Museums. Sitzber. Akad Wiss Wien 61: 336-350.

STrauch A. 1887. Bemerkungen über die GeckonidenSammlung in Zoologischen Museum der Kaiser- lichen Akademie zu St. Petersburg. Mém Acad Impér Sci St Petersbourg (7) 35 (2): 1-73.

TriCART J. 1958. Division morphoclimatique du Brésil atlantique central. Ver Géomorph Dynam 9 (1-2): $1-22$.

UNDERWOOD G. 1954. On the classification and evolution of geckos. Proc Zool Soc London 124 (3): 469-492.

VANZOLINI PE. 1953. Sôbre a diferenciação geográfica de Gymnodactylus geckoides (Sauria, Gekkonidae). Papéis Avulsos Zool 11 (14): 225-262.

VANZOLINi PE. 1974. Ecological and geographical distribution of lizards in Pernambuco, northeastern Brazil (Sauria). Papéis Avulsos Zool 28 (4): 61-90.

VANZOLINI PE. 1977. An annotated bibliography of the land- and fresh-water reptiles of South America (1758-1975). Vol. 1 (1758-1900). S. Paulo: Museu de Zoologia da Universidade de S. Paulo. iv + 316p.

VAnZolini PE. 1978. Lepidoblepharis in Amazonia (Sauria, Gekkonidae). Papéis Avulsos Zool 31 (13): 203-211.

VAnZolini PE. 1982. A new Gymnodactylus from Minas Gerais, Brazil, with remarks on the genus, on the area and on montane endemisms in Brazil (Sauria, Gekkonidae). Papéis Avulsos Zool 34 (29): 403413.

VANZolini PE. 1993. Métodos estatísticos elementares em sistemática zoológica. S. Paulo: Editora Hucitec, 130p.

VANZOLINI PE. 1997. The silvestrii species-group of Amphisbaena, with the description of two new Brazilian species. Papéis Avulsos Zool 40 (3): 65-85.

VANZOLini PE. 2002. A second note on the geographical differentiation of Amphisbaena fuliginosa L., 1758 (Squamata, Amphisbaenidae), with a consideration of the forest refuge model of speciation. An Acad Bras Cienc 74: 609-648.

VAnzolini PE AND Heyer WR. 1988. Proceedings of a workshop on Neotropical distributional patterns held 12-16 January 1987. Rio de Janeiro: Academia Brasileira de Ciências, 488p.

Vanzolini PE, Ramos-Costa AM and Vitt LJ. 1980. Répteis das caatingas. Rio de Janeiro: Academia Brasileira de Ciências. 161p., pls.

Velloso AL, Sampaio EVSB and Pareyn FGC, eds. 2002. Ecorregiões propostas para o bioma caatinga. 
Recife: Assoc. Plantas do Nordeste; Inst. Conserv. Ambient.; The Nature Conservancy do Brasil. 76p., maps.

Veloso HP, Goes-Filho L, Leite PF, Barros-Silva SD, Ferreira HC, Loureiro RL and Terezo EFM. 1975. Vegetação. As regiões fitogeográficas, sua natureza e seus recursos econômicos. Estudo fitogeográfico, p. 305-403 in Projeto Radambrasil, Levantamento de Recursos Naturais vol. 8 .

WAGLer J. 1830. Natürliches System der Amphibien... Munich, Stuttgart and Tübingen: J.G. Cotta. vi + 352p.
Wiegmann AFA. 1834. Herpetologia Mexicana seu descriptio amphibiorum Novae Hispaniae quae itineribus... Berlin: C.G. Luderitz. vi +54 p., pls.

Williams EE and Vanzolini PE. 1980. Notes and biogeographic comments on anoles from Brazil. Papéis Avulsos Zool 34 (6): 99-108.

Wright S. 1967. Comments on the preliminary working papers of Eden and Waddington. Wistar Inst Symp Monogr 5: 117-120.

ZAR JH. 1999. Biostatistical analysis. Fourth edition. Upper Saddle River, New Jersey: Prentice-Hall. xii +663 etc. 